\title{
The Po Plain Loess Basin (Northern Italy): Scientific Values, Threats, and Promotion Opportunities
}

\author{
Irene M. Bollati ${ }^{1}$ D $\cdot$ Andrea Zerboni $^{1}$ (D) \\ Received: 13 January 2021 / Accepted: 7 July 2021 / Published online: 3 August 2021 \\ (c) The Author(s) 2021
}

\begin{abstract}
Geoheritage studies periodically propose assessment methodologies addressed to quantify the value of sites of interests towards geoconservation and/or promotion. Loess outcrops in the Po Plain Loess basin (Northern Italy) represent potential geoheritage sites, allowing to reconstruct glacial and interglacial cycles, testifying evidence of paleoseismicity, and preserving traces of Palaeolithic human exploitation along the foreland of the Alpine and Apennine ranges. In this contribution, firstly we propose a brief review on the loess sites in the framework of geoheritage studies. Then, we evaluate the 6 most significant loess outcrops scattered across the Po Plain Loess Basin (Monte Netto Hill, Val Sorda Sequence, Gajum Section, Ghiardo Plateau, Valenza Section, Torino Hill) applying a quantitative methodology aimed at ranking each locality respect to a benchmark site - the Romanengo Plateau - which is the sole loess site included in the Italian Inventory of Geosites. The $70 \%$ of sites obtained a global value higher than our benchmark. They show a high diversity, not only from the scientific point of view (i.e., site-intrinsic geodiversity), but also when we consider their Potential for Use. Despite often disregarded in the international panorama, Italian loess sites require a great attention. Moreover, such sites are evolving passive geomorphosites, thus potentially vulnerable from natural and human causes: this must be considered in the framework of geoconservation and sustainable promotion of each site. Finally, we discuss the possibility of promoting Italian loess sites through different strategies (e.g. virtual tours, 3D models, and gamification based on landscape reconstruction) allowing to visit them by remote and favouring promotion. At the same time, this approach will also promote geoconservation, improving awareness in the general public on the relevance of such sites for Earth (natural and human-related) history.
\end{abstract}

Keywords Loess outcrops · Geoheritage sites assessment · Geodiversity $\cdot$ Vulnerability $\cdot$ Promotion strategies $\cdot$ Po Plain (Northern Italy)

\section{Introduction}

Quaternary loess deposits and complex pedosequences developed into wind-blown silt as parent material are very powerful palaeoclimatic and palaeoenvironmental indicators (Pye 1995). Loess sequences are distributed along wide latitudinal ranges in both the Boreal and Austral Hemispheres: at high and mid-latitudes, loess deposits and related palaeosoils allow reconstructing glacial and interglacial cycles; whereas at lower latitudes, loess is generally related to arid conditions and expansion of desert margins (e.g. Kukla

Irene M. Bollati

irene.bollati@unimi.it

1 Dipartimento di Scienze Della Terra “A. Desio”, Università degli Studi di Milano, Via L. Mangiagalli 34, 20133 Milano, Italy
1977; Heller and Liu 1982, Pecsi 1990; Crouvi et al. 2010; Marković et al. 2015; Wang et al., 2019; Lehmkuhl et al. 2021). For this relevant scientific value, loess outcrops are acquiring great attention in the framework of geoheritage identification. The distribution of loess deposits all around the world has been quantified at about $10 \%$ of Earth's surface (e.g. Heller and Evans 1995; Smalley et al. 2011). Yet, loess covers are relatively rare if compared to other kinds of Quaternary sediments, and often characterized by a hotspot like distributions, implying that a very careful analysis of the most suitable strategies for geoconservation versus promotion is required. Moreover, the specific values and threats to loess sites of interest must be determined before to propose any form of promotion (Reynard et al. 2007; Baadi et al., 2020).

Due to their complexity, loess sequences can be categorized as: (i) geosites of stratigraphic (or tectonic) interest 
(sensu Grandgirard 1999), if the scientific value of the sites is considered mainly related to the reconstruction of the geological history of a region; and (ii) geomorphosites (sensu Panizza 2001), when considered as landscape units undergoing pedogenesis, linear erosion, slope deformation, and erosion, which may generate spectacular gullies, representing very relevant landmarks from an aesthetic point of view (Warowna et al. 2016). According to recently proposed approaches (e.g. Bollati et al. 2017), these meanings find correspondence respectively into the geological representativeness (i.e., stratigraphy and tectonics), the geomorphological representativeness within the scientific value assessment as a geoheritage site, and also into the aesthetic value among the additional values.

Processes contributing to shape spectacular gullies also represent a severe natural threat for loess strata (Vasiljević et al. 2011a, 2014; Wang et al. 2019). Being these ongoing natural processes different from the genetic one, loess sites could rely in such cases within the category of evolving passive geomorphosites (see Pelfini and Bollati 2014) that are featured by a great vulnerability (sensu Garcìa-Ortiz et al. 2014). In fact, the pristine process of aeolian deposition and soil-forming are no more active, and the related ancient landforms are dissected by secondary processes. Solarska et al. (2013) underlined too the importance of distinguishing both primary landforms (related to the deposition of loess sequences by wind action) and secondary landforms (gullies and scarps dissecting previous landforms), to propose more adequate management strategies.

Considering such a variety of perspectives, loess outcrops are relevant also for educational and geotouristic purposes (e.g. Vasiljević et al. 2011a; 2014; Vujičić et al. 2011; Solarska et al. 2013; Višnić et al. 2013; 2016; Warowna et al. 2016; Wang et al. 2019), with a special regard to their geoarchaeological value (i.e., cultural value; Vujičić et al. 2018). The North and South American loess basins, the Eurasian loess belt, which includes among the other the Chinese Loess Plateau, and the desert loess belt of North Africa are among the most important loess districts of the world (Vasiljević et al. 2014; Lehmkuhl et al. 2021). Notwithstanding this, several other (smaller) loess basins are distributed in the world regions where contrasting climatic conditions alternated across the Quaternary ( $\mathrm{Li}$ et al. 2020). The list of these areas - often disregarded - includes the Upper Pleistocene Po Plain Loess Basin of Northern Italy (Amit and Zerboni, 2013; Zerboni et al. 2018), where several loess/ paleosol outcrops display complex pedosequences formed under contrasting Pleistocene pedoclimatic settings, recording recent tectonic activity in the foreland of the Alpine and Apennine ranges, and preserving open-air Palaeolithic archaeological sites (e.g. Cremaschi 1990; 2004; Ferraro 2009; Cremaschi et al. 2015; Zerboni et al. 2015; Frigerio et al. 2017; Delpiano et al. 2019).
Starting from a brief state of the art on loess in geoheritage studies, a detailed analysis on potentialities of selected sites from the Po Plain Loess Basin is here discussed. In this region, after the first attempt made by Cremaschi (1990), the drawing of a loess map is still in progress (Zerboni et al. 2018). Recently, major outcrops underwent new investigations, and a fresh mapping has been addressed considering the loess landscapes of Europe (Lehmkuhl et al. 2021). The aims of this paper are (i) to provide a general overview on geoheritage research regarding loess outcrops as a specific category of geoheritage site, in terms of scientific and additional values, the potential for use and threats; and (ii) to select by ranking among potential loess geoheritage sites in the Po Plain loess basin (Northern Italy), using an already tested methodology and discussing the results in terms of geoconservation and/or promotion strategies. A particular focus will be posed to geodiversity features.

\section{State of the Art on Loess Deposits in Landscape and Geoheritage Analysis}

\section{Genesis, Age, Geographical Distribution, and Related Landscapes}

From an historical point of view, the term "Loess" derives from the German Löss or Lö $\beta$, meaning "loose", a term associated to this kind of deposits by peasants and masons in the Rhine region (Višnić et al. 2013 and reference therein). Initial identifications of loess deposits in Europe were performed by Luigi Ferdinando Marsigli during the seventeenth and eighteenth centuries (Marković et al. 2004); Karl Cäsar von Leonhard, who described loess deposits as yellowish brown and silty along the Rhine valley; and Charles Lyell. The father of the modern Geology ratified the use of the word "loess" in 1834 after observing similarities between loess and loess derivatives in Rhine and Mississippi riverine environments (Višnić et al. 2013 and reference therein).

Regarding their genesis, loess deposits are mainly silty sized wind-blown sediments that, according to different authors (e.g. Kukla 1977; Heller and Liu 1982, Cremaschi 1990; Pecsi 1990; Pye 1995; Crouvi et al. 2010; Vasiljević et al. 2011a; Marković et al. 2015; Wang et al. 2019; Lehmkuhl et al. 2021), are typical of glacial periods featured by dry environmental conditions and strong winds that allow the transportation of grinded materials. While loess deposits indicate dry and/or cold climate conditions, palaeosoils occasionally intercalating with loess strata and developed in it indicate they formed under less arid to warm/humid climates. Loess deposition over extensive areas at mid-latitudes regions has proceeded quite continuously during the Quaternary (Vasiljević et al. 2011a; 2014; Muttoni et al. 2017), forming several-tens to hundred meters' thick deposits. The 
most suitable deposition areas are identified by Vasiljević et al. (2014) in the plains, plateaus, hills, and river basins.

Loess deposits are particularly susceptible to waterrelated processes that may generate a wide variety of landforms. The relatively high cohesion of loess deposits when they are dry and susceptibility to the erosion impact of ephemeral flows (Warowna et al. 2016) favour the genesis of a typical loess relief or loess landscape (Solarska et al. 2013), mainly consisting of gullies, dry valleys, infilling of closed depressions, accumulation on escarpments, and draping previous topographies (Pye, 1995). The pristine topography is a further factor controlling the evolution of loess landscapes. In specific cases, one of the most impressive morphological features - a landmark of loess areas — are gullies (Warowna et al. 2016), very highly valued features from the geoheritage and geotourism point of view (Zgłobicki et al. 2015). Wang et al. (2019) surveyed the Luochan Loess National Geopark, suggesting the presence of a high geodiversity in landforms (i.e., geomorphodiversity, Panizza 2009): steep hanging gullies, short rills, pillars dissected by vertical joints and fissures favouring long-term weathering and erosion, columns, and bridges. The same authors also proposed a classification of loess columns types: sharp, square, mother-son, parasitic, forest, giant, red-clay, and loess walls. Vasiljević et al. (2014) reported the presence of the following loess-related landforms in the Serbian region: gorges, wavy plateaus, steep profiles, pseudo-karst landforms, caves, sinkholes, dry valleys, gullies, and pyramids. Pseudokarstic landforms formed by piping are reported also by Lukić et al. (2009). Solarska et al. (2013), finally, listed and described the following loessrelated landforms in the Polish territory: reliefs; covers and related enhanced or buried topography scattered into islands or ridges; morphological edges related more or less to older geological relief and lines; plateaus with, in case, gullying affecting borders; and gully systems related to natural but also anthropogenic conditions (e.g. intensive land use as agricultural terraces). All these features testify to the geomorphodiversity that is intrinsic (sensu Panizza 2009) to loess regions (Solarska et al. 2013).

Concerning the geographical distribution of the loess outcrops all around the world, Heller and Evans (1995) and Smalley et al. (2011) suggest that the about $10 \%$ of Earth's surfaces is covered by wind-blown silt. Most of them are distributed between China and Europe, along the Eurasian loess belt (Vasiljević et al. 2014). In central and eastern Asia extensive, thick, and continuous loess deposition exist; they started forming 22 My ago (Guo et al. 2002). A 1/5 of Europe surface is covered by loess and loess like sediment (Haase et al. 2007; Lehmkuhl et al. 2021), especially in the Danube area and Pannonian basin, where the percentage of regional coverage reaches the $60 \%$ (Vasiljević et al. 2011a). Moreover, according to Markovic et al. (2011), the Danubian and Pannonian basin represents the most detailed archive for Pleistocene climatic and environmental fluctuations in Europe. Other regions in the world are interested by widespread loess deposits: Northern America (Muhs and Bettis, 2003), Southern America (Kröhling 1999; Zárate 2003), North Africa (Crouvi et al. 2010), and New Zealand (Smalley 1995).

Along the Mediterranean basin, loess sequences are also present (Cremaschi 1990; Crouvi et al. 2010). Considering Italy, loess outcrops are shallow but very common (Cremaschi 1990) and quite always neglected in loess distribution maps at continental scale (e.g. Muhs 2007; Solarska et al. 2013). Both Smalley (1995) and Haase et al. (2007), reporting the presence of major areas of loess in Europe other than the Pannonian basin the first, and drawing the Loess Map of Europe the second, included secondary evidence from the Po Plain. In fact, loess outcrops in Northern Italy are often considered loess derivate or secondary loess deposits or soils developed on loess (e.g. Lindner et al. 2017), thus precluding their insertion in reconstruction at continental scale (Amit and Zerboni 2013; Zerboni et al. 2018). Only recently, a review on loess in Europe and its regional differentiation (Lehmkuhl et al. 2021) included the Italian loess as "proper loess", defined as "Mediterranean loess". As a matter of fact, during Pleistocene interstadials and after the LGM, loess deposits underwent pedogenesis (Cremaschi, 1990) and reworking due to natural surface processes, which intensity was sometimes increased by human agency (Cremaschi et al. 2015). For that reason, Italian loess sequences and pedosequences sometimes miss some of the typical features of classical loess described by Haase et al. (2007). On the other hand, in a region like the Po Plain foredeep, loess could have additional values, preserving palaeoseismological evidence in areas considered to have low seismic risk (Livio et al. 2014), as described in detail below.

More in depth, along the Italian peninsula loess cover extensive parts of North Italy (Cremaschi, 2004) and accumulated along the coastlines mostly during MIS 4 to MIS 3 , with less extensive occurrence in the Last Glacial Maximum (LGM) and Lateglacial periods (Cremaschi et al. 2015; Badino et al., 2020; Peresani et al., 2021). According to Zerboni et al. (2015), most of the loess sequences of the Po Plain Basin date to the Upper Pleistocene and were deposited mainly between $75-16 \mathrm{ky}$ ago. The scattered distribution of loess deposits in Northern Italy is similar to the Polish cases described by Solarska et al. (2013), and a first attempt to draw a map of loess occurrences in Northern Italy was made by Ferrari and Magaldi (1976), Cremaschi (1990), Cremaschi et al. (2015), and recently by Zerboni et al. (2015). Some information is reported also in the LGM map by Vai and Cantelli (2004). Zerboni et al. (2018), with the aim of drawing a specific map of loess outcrops distribution in Northern Italy, list the potential trap areas in 
such a foreland context: glacial sediments and fluvioglacial deposits, karts plateaus and sinkholes, isolated hills in the Po Plain formed after tectonic deformation, glacis and erosional surfaces.

Most of loess sequences in the Po Plain can be considered as complex pedostratigraphic sequences (Zerboni et al. 2015), because they include wind-blown sediments and palaeosoils (related to interglacial periods) developed into loess. Hence, in this area both simple and complex pedosequences could be retrieved, including localities where loess levels are intercalated to paleosols, preserve evidence of past earthquakes, and entomb archaeological remains (Livio et al. 2014; Cremaschi et al. 2015; Delpiano et al. 2019).

\section{Loess Outcrops and Landscapes as Potential Geoheritage Sites}

As mentioned above, loess outcrops could be intended as geosites of stratigraphic (or tectonic) interest (sensu Grandgirard 1999) or geomorphosites (sensu Panizza 2001), satisfying both the definitions because enclosing the respective features. During the last years, the interest towards soft-rock geomorphosites, like loess outcrop may be intended, has been increasing, and they have been considered as important as hard-rock geosites (Vasiljević et al. 2011b). According to the categories of geological World Heritage sites proposed by Dingwall et al. (2005) and revised by Vasiljević et al. (2011a; b), loess sites could be intended as stratigraphic site, ice age site, and arid semi-arid landscapes and landforms sites. Specific attributes and values are recognized to this kind of geoheritage sites (Solarska et al. 2013), and different authors (e.g. Vasiljević et al. 2011a; 2014; Wang et al. 2019) analyze in detail their potential features, summarized in Table 1, and discussed in the following section.

The scientific and educational values listed in the first category (A in Table 1), and the core features for establishing a geoheritage site, are related to the potentiality of these sites to witness the Earth's climate history, representing an important terrestrial palaeoclimatic and palaeoenvironmental archives (Dong et al. 2014; Vasiljević et al. 2014; Višnić et al. 2016). For instance, Chinese loess sequences are particularly relevant in this category: covering continuously a few million years, they are a fundamental continental archive, also as compared with the other palaeoclimatic proxies (Vasiljević et al. 2011a). Interlayered palaeosoils could serve also as markers, and they could be compared with recent environmental analogues (Vasiljević et al. 2011a). For the scientific value, palaeontological remnants preserved in loess strata can also be considered. Anyway, this feature was instead depicted by Vasiljević et al. (2014) as a component of the cultural value (Table 1).

Loess landscapes, as described by Solarska et al. (2013), are characterized by all the above-mentioned potential loess landforms. As geodiversity is considered among the funding

Table 1 Global values of loess outcrops as geoheritage sites according to Vasiljević et al. (2011a; 2014) and Wang et al. (2019)

\begin{tabular}{|c|c|}
\hline Values & Sub-values \\
\hline $\begin{array}{l}\text { A. Research and education values } \\
\text { (scientific) }\end{array}$ & $\begin{array}{l}\text { Scientific discovery related to Earth surface history and evolution: significant palaeoclimatic and pal- } \\
\text { aeoenvironmental record represented by pedosequences formed under glacial and interglacial phases } \\
\text { History of research: stratigraphic reference sections } \\
\text { Environmental monitoring: palaeoenvironmental and palaeoseismological indicators } \\
\text { Education and training practical studies of Geology and Earth Sciences }\end{array}$ \\
\hline B. Cultural values & $\begin{array}{l}\text { Folklore, tradition and spiritual beliefs } \\
\text { Archaeological } \\
\text { Historical } \\
\text { Palaeontological }\end{array}$ \\
\hline C. Aesthetic values & $\begin{array}{l}\text { Local landscapes: hills, gullies, gorge, steep profiles, loess quarries } \\
\text { Leisure activities: paragliding } \\
\text { Remote appreciation: distance from towns } \\
\text { Artistic inspiration }\end{array}$ \\
\hline D. Economic values & $\begin{array}{l}\text { Construction materials: brickyard quarries } \\
\text { Fertile soils (agriculture and vegetation) }\end{array}$ \\
\hline E. Functional values & $\begin{array}{l}\text { Platforms: agriculture, traffic, constructions } \\
\text { Storage and recycling: waste disposal } \\
\text { Health: electromagnetic radiation cuts off, beauty medical skin treatments, pillow and mattress industry } \\
\text { Burial graveyards } \\
\text { Water chemistry: springs } \\
\text { Soil function: parent materials }\end{array}$ \\
\hline
\end{tabular}


attributes of the scientific value of geomorphosites (Bollati et al. 2017 and reference therein), loess geodiversity adds a potential greater value to outcrops. Despite the importance of this parameter, it has not yet considered in literature among the values of loess sites for geoheritage analyses (Table 1).

The cultural (and social) values of loess (B in Table 1) are mainly related to the archaeological record of loess (Vujičić et al. 2018) and its role in the development of civilization at least since the Neolithic, especially in relation with the great fertility of loessic soils (Solarska et al. 2013) and with specific favourable topographic features (e.g. Solarska et al. 2013; Zgłobicki and Baran-Zgłobicka 2012). Early Medieval settings coincide with towns built on the top of loess hills in Poland (Solarska et al. 2013). Moreover, in Europe, Asia, and occasionally in North Africa, loess deposits include Palaeolithic (and later) archaeological sites (Romanowska 2012; Cremaschi et al. 2015; Fitzsimmons et al. 2020), as hunter groups left the remains of their campsites (Delpiano et al. 2019). The tight relationship between Pleistocene human groups and loess is evident also in a number of cave sites, where wind sedimentation is one of the most common sedimentary processes (Laville et al. 1980; Cremaschi 1990; Cremaschi and Ferraro 2007; Krajcarz et al. 2016; Hirniak et al. 2020; Spinapolice et al., in press). Boukhchim et al. (2018) focused their attention on cave dwellings in loess in Tunisia.

Among the other possible values of loess outcrops in term of geoheritage, we may consider the aesthetic value ( $\mathrm{C}$ in Table 1). It could be related to the different landforms described in literature, reported before (Solarska et al. 2013; Warowna et al. 2016; Vasiljević et al. 2014; Wang et al. 2019). As for all the geoheritage sites, the enhancement potential of loess areas depends significantly on the attractiveness of these loess landscapes, derived from the interaction of natural processes inducing gullying in loess and human intervention. In the case of intense exploitation, the aesthetic value of loess outcrops could be shattered, as, for example, at brickyard and quarry sites (Vasiljević et al. 2011b); in other cases, human intervention could enhance the aesthetic value (Boukhchim et al. 2018) and accessibility of outcrops (see examples among the study cases).

Experiences on quantitative assessment addressed to the selection of loess sequences as geoheritage elements were performed in Europe: Warowna et al. (2016) evaluated the most suitable sites to propose a loess-related geopark in Poland; Serbian scholars (Vujičić et al. 2011; 2018; Višnić et al. 2016) proposed a specific procedure aimed at detecting the most suitable loess sections for geotourism purposes in the Serbian loess plateau. Considering more in detail the application of the Geosite Assessment Model (GAM), authors included some of the values proposed in Table 1 (scientific/educational, scenic/aesthetic, functional, protection, tourism), detailing very systematically the subvalues in order to perform a strict quantification. The method uses to evaluate also the degree of vulnerability and potential damages, besides the damages already occurred to the sites. All the evaluated sites testify the high scientific value of loess profiles, while, as in other region of the world, touristic infrastructures are still poorly developed, affecting the potential for geotourism. Recently, several authors used the GAM procedure to test the results obtained by two groups of evaluators (i.e., geoscientists and archaeologists) using different weights for each criterium, especially focusing on the cultural value of loess sites. Hence, the GAM provides a model to assist in the sustainable planning and management of natural heritage (with a focus on loess sites) and their transformation into tourism destination.

Višnić et al. (2016) in a further analysis compared their results with those obtained through other methods of assessment (e.g. Jovanović and Zvizdić 2009) that customized to loess sites of the geomorphosite assessment model proposed by Reynard et al. (2007). Depending on the tourist demand, the authors distinguished between factors that are internal (intrinsic) or external. In this methodology, the ecological value of sites, which is rarely taken into account in geomorphosite methodologies (Bollati et al. 2015), is considered among the external factors (Višnić et al. 2016). According to the literature reviews proposed by Bollati et al. (2015), the ecological support role is herein proposed among the scientific attributes, thus being an intrinsic factor for which more in-depth investigations are worth.

\section{Threats to Loess Geoheritage Sites}

As loess sites are "soft-rock geomorphosites" (Vasiljević et al. 2011b), several threats could have disruptive and permanent effects on them. Table 2 includes the systematic reviews on the threats affecting loess section proposed in literature (Lukić et al. 2009; Vasiljević et al. 2011a; 2014; Wang et al. 2019).

One of the main issues threatening the conservation of loess sections is natural erosion, increased by sparse vegetation and heavy rainfall. For instance, monsoonal precipitation induces strong erosion on loess in the China area (Vasiljević et al. 2014). In some areas of Europe, the problem is related to the low thickness of loess sections, which, if affected by erosion, can be totally dismantled, thus losing their value as record of past palaeoclimates/ palaeoenvironments. Wang et al. (2019) analysed the geological hazard threats in relation to geotechnical properties of loess deposits and their interaction with waterrelated processes, since potentially affecting tourist visit to the sites: this is a relevant issue also for Warowna et al. (2016). Wang et al. (2019) performed geotechnical tests to understand relation between water, freeze-thaw cycle, 
Table 2 Summary of factors threatening loess outcrops as geoheritage sites according to Vasiljević et al. (2011a; 2014) and Wang et al. (2019)

\begin{tabular}{|c|c|c|}
\hline Threat origin & Threat inducement & Details \\
\hline \multirow[t]{6}{*}{ A. Natural } & Erosion: & Fall \\
\hline & $\begin{array}{l}\text { Sections near rivers are directly influenced by fluvial ero- } \\
\text { sion }\end{array}$ & \\
\hline & Features in loess influenced by water runoff (heavy rainfall) & \\
\hline & Earthquake & \\
\hline & Freeze-thaw cycle and exfoliation & Landslides \\
\hline & Piping & Exfoliation, landslides \\
\hline \multirow[t]{9}{*}{ B. Human-induced } & Functionality/economical & $\begin{array}{l}\text { Agriculture and urbanisation: } \\
\text { - Vegetation change caused by agricultural activities } \\
\text { - Mechanical devastation of loess exposures } \\
\text { - Illegal construction of buildings } \\
\text { - Unplanned urban expansion }\end{array}$ \\
\hline & & Extraction: brickyards exploiting loess sections \\
\hline & Legislative framework & Unfavourable legislation \\
\hline & & Negative ownership \\
\hline & $\begin{array}{l}\text { Ignorance: lack of information or education, no sense for } \\
\text { nature protection and intrinsic values of geodiversity }\end{array}$ & $\begin{array}{l}\text { Waste disposal: } \\
\text { - Former brickyard outcrops often used as waste disposal } \\
\text { locations } \\
\text { - Local, small, junkyards on remote and hidden loess sections } \\
\text { near } \\
\text { - Settlements }\end{array}$ \\
\hline & & $\begin{array}{l}\text { Uncontrolled vegetation growth reduces visibility of loess } \\
\text { sections }\end{array}$ \\
\hline & & $\begin{array}{l}\text { Recreation/tourism effects: garbage, fires, barbecue places, } \\
\text { flora and fauna degradation, caused by recreationists, local } \\
\text { people, visitors }\end{array}$ \\
\hline & & Removal of geological elements at brickyards and urban areas \\
\hline & & Military: not regulated practice fields \\
\hline
\end{tabular}

and the temporal interval favourable to instability. Landslides occurrence at several sites could be significant: for instance, some Poland towns are built on loess deposits covering older substrate, and they are prone to additional and specific hazards (Solarska et al. 2013). Lukić et al. (2009) suggest the existence of ephemeral piping-related (pseudokarstic) landform developed on loess bodies and their very limited lifetime due to the intrinsic erosional nature of the formative process.

In most cases, human-induced threats are also related to the values of loess outcrops. For example, the economic and functional values (see Table 1, D, economic; E, functional values) induce an extreme pressure. One of the most impacting human activities is surely related to brickyards, leaving in some European areas only a few integers of significant palaeo-pedocomplexes (Vasiljević et al. 2011a). Vasiljević et al. (2014) highlighted that another deep impacting human agency is related to agricultural exploitation. Yet, the extensive use and exploitation for the aesthetic value of loess landscapes could compromise some sites (Vasiljević et al. 2014). A borderline situation between cultural value and threats is the case of loess outcrops used for loess cave dwellings, as, for example, in Tunisia (Boukhchim et al. 2018).
Positive effects of human exploitation, anyway, are related to the discovery of loess sequences for their scientific features and/or for the coming to light of archaeology remnants (Romanowska 2012). In this case, the sustainable development of activities deriving from a collaboration with managers and local authorities could prove to be fundamental (Vasiljević et al. 2011a; 2014).

\section{Promotion and Geoconservation Strategies for a Possible Sustainable Exploitation of Loess Geoheritage Sites}

Considering the analysis on threats from natural and human causes, some useful measures are suggested in the literature for a sustainable management of loess geoheritage sites: (i) warning signs for both (positive) geoheritage values and (negative) geological hazards; (ii) fences to protect sites from human extraction for scientific and economic uses; (iii) reinforcements to prevent erosion; and (iv) monitoring points at opening fissures in loess outcrops. Worldwide no specific legislation is addressed to protect loess areas: only some specific areas were considered for preservation along the Eurasian loess belt, but with problems related to funding 
(Vasiljević et al. 2014). As already mentioned, occasionally the cooperation with private companies extracting sediments may support geoconservation interventions: for example, they can preserve specific part of loess outcrops from natural- and human-related risks (Vasiljević et al. 2011a; 2014). In Germany, for instance, a loess site included in a dismissed quarry was re-vegetated improving its conservation and allowing the insertion of the site within a global geopark characterized by other types of geological heritage (Antoine et al. 2001). According to Zhao et al. (2015), loess geoparks fall into the category of stratigraphic relic and geological landforms geoparks, of the classification proposed by UNESCO (2010). The Chinese experience is the most advanced in term of loess-related geoparks. Wang et al. (2019) underline how the only geopark named after loess in the world is the Luochen Loess Geopark, even if 3 more Chinese geoparks include relevant loess features (Vasiljević et al. 2014). Other examples of loess sections included into geoparks are from Austria, Slovakia, and UK (Vasiljević et al. 2011a). Warowna et al. (2016), considering the geopark situation of Europe, refer that a few examples of geoparks are associated to loess outcrops. They also aimed, through the quantitative assessment of loess sites of outstanding value, at creating the first geopark in Poland - and first in Europe - presenting at a broad scale a thematic park related to loess geoheritage. Vasiljević et al. (2011b) underlined, anyway, the general difficulty that could emerge in setting up a geopark related to small and scattered areas. According to the authors, this kind of geopark would be insufficiently large to promote the local economic and socio-cultural development, which is one of the suggestions discussed in the guidelines of the Global Geoparks Network.

Vasiljević et al. (2011a; 2014) proposed a step-like strategy towards geoconservation and promotion of loess outcrops: (i) to perform an inventory of loess profiles and sections of a region for selecting the most representative ones for geoconservation; (ii) to identify threats for each selected site; (iii) to elaborate specific policies including restriction of access and permits release only to specific categories of people; (iv) to propose a synergy between researchers all around the world for studying specific strategies for promotion, including the launch of national and international projects as the Loessland Project (Vasiljević et al. 2011a; 2014; Višnić et al. 2013) or the Polish Loess Land (Solarska et al. 2013); and (v) to focus on education, interpretation, and promotion (visitor centres, dedicated events, editing of web-based interactive maps, adoption of multidisciplinary approaches; Vasiljević et al. 2009; 2011b) in a sustainable way to fight threats related to ignorance (Warowna et al. 2016; B, Human-induced in Table 2).

Moreover, in consideration of the sparse distribution of loess outcrops in some regions and to overcome the difficulty in setting up a geopark in Serbia, Vasiljević et al. (2011b) propose a specific approach, which can be successfully adopted in similar contexts. They propose two solutions addressed to scattered loess outcrops for being enhanced and sustainably managed: (i) to attribute to loess sites of the status of Natural Monument or Geosites, thus including them in national inventories, and (ii) to network loess sites (loess geotourism localities) through thematic routes across a region. The last strategy was also suggested by Warowna et al. (2016), who set up 4 geotrails linking loess geosites in Poland.

\section{Methods for Loess Sequence Evaluation as Potential Geoheritage Sites}

Despite the importance of proposing methodologies suitable for the quantitative evaluation of different categories of geoheritage sites (Baadi et al. 2020), some methodologies applied in literature are aimed at assessing certain types of geoheritage sites (e.g. geomorphosites; see a review in Brilha 2016), sometimes very specific (e.g. anthropogenic landforms, Kubalikova et al. 2019; rock cliffs equipped for climbing; Bollati et al. 2016). In this last case, the authors pose the emphasis on definite features decided time by time. In this framework, the aims of the assessment should be clear, from the beginning, in terms of topics, value, scale, and use (De Lima et al., 2010). In our specific case, the aim is the ranking of a particular type of geoheritage sites (i.e., loess outcrops; e.g. Vujičić et al. 2011; 2018; Višnić et al. 2016) for analysing their geodiversity at regional scale and for understanding their potential for being promoted, as witnesses of specific paleoenvironmental and geological topics, taking into account also their vulnerability (sensu GarcìaOrtiz et al. 2014). According to this last aspect, specific methodologies (e.g. Baadi et al. 2020) have been recently proposed to quantify also the degree of deterioration of a site considering different features like vulnerability, fragility, and human pressure on the site, weighting the criteria aspiring to reach the greater objectivity during the evaluation procedure.

The first step of loess outcrop investigation consisted in the analysis of the national and regional inventories of geosites, in order to detect the occurrence of loess sites in the Italian framework, that could be a first step towards their protection. According to these results, the quantitative assessment of a regional selection of loess sequences was focused at the scale of the Po Plain, the most relevant loess basin in the Italian territory. Among the selected sites undergoing evaluation, the unique site inserted in the ISPRA National (Italian) Inventory of Geosites (http://sgi. isprambiente.it/GeositiWeb/Default.aspx) was considered as benchmark for discussing the ranking of the other sites and the opportunity of making new proposals to the ISPRA 
database managers, also for planning sustainable promotion strategies for these sites.

The assessment method is the one proposed specifically for geomorphosites by Bollati et al. (2017), and also applied with adaptations to rock cliffs equipped for climbing (Bollati et al. 2016). Data were organized by means of a relational database realized using a commercial package (Microsoft Office Access ${ }^{\circledR}$, version 2016), providing final numeric values to rank the sites. The database was set using the evaluation parameters (i.e., macrovalues), whose components are reported in the Supplementary Materials A and B: Scientific Value (SV), Additional Values (AV), Global Value (GV) (Supplementary Material A) and the Potential for Use (PU) (Supplementary Material B). Moreover, two specific indices were computed to define the scientific and the educational potential of the sites: Scientific Index (SIn) and Educational Index (EIn) (Supplementary Material C).

For instance, the site-intrinsic geodiversity attribute that falls within the Scientific Value is based upon the geodiversity categorization suggested in the literature, with different shades (e.g. Pereira and Pereira 2010; Bollati et al. 2016; Baadi et al. 2020). This attribute is calculated considering the different geological features featuring the site (e.g. how many lithologies, how many geomorphological features): the more are the features, the higher is the value of the site.

Moreover, considering the global values of loess geomorphosites according to Vasiljević et al. (2011a, 2014) and Wang et al. (2019), reported in Table 1, their correspondence with the values herein applied is highlighted in the Supplementary materials (A, B).

\section{Description and Ranking of Loess Outcrops as Potential Geoheritage Sites in the Po Plain Loess Basin}

In Italy, relevant pedological sites and sequences (i.e., pedosites) are inventoried in the interactive map, based on Google Earth "Soil cultural heritage of Italy" (Costantini and L'Abate 2009). The Italian National Inventory of Geosites (http://sgi.isprambiente.it/GeositiWeb/Default.aspx; last visit on 14th December 2020) up to now includes only 1 loess site: the Romanengo Plateau. Yet, major parts of the Po Plain preserve loess outcrops with a real scientific relevance for reconstructing the glacial/interglacial evolution of northern Italy as much as the geological dynamicity of the region and the interaction between past climate change and human peopling. As discussed above, loess landscapes have relevant scientific, aesthetic, and touristic values. In the case of the Po Plain, loess outcrops are much more scattered, and covers are less continuous than in other regions (e.g. the Danubian and Pannonian basins). Therefore, a comprehensive presentation of loess in the Po Plain becomes challenging, and we prefer to focus on the analyses of the major outcrops. In this framework, the following sites were considered for the quantitative evaluation: Torino Hill, Val Sorda Sequence, Monte Netto Hill, Gajum Section, Ghiardo Plateau, Valenza Plateau, Romanengo Plateau (Fig. 1). The assessment results are accompanied by a description of each site; moreover, values of each loess site are compared to provide a ranking. The results of the quantitative evaluation are illustrated in Figs. 2 and 3. The radar graphs of Fig. 3 need to be interpreted basing on the knowledge of each site, and not taken as they are, since the area covered by the geosite values could differ according to the order of disposition of the macrovalues around the centre (Reynard et al. 2016). Moreover, the radar graph is used to compare the site-intrinsic geodiversity attributes among sites.

\section{The Pianalto di Romanengo Plateau: The Benchmark Site}

The Pianalto di Romanengo Plateau is the surface expression of buried deformative structures linked to the deep dynamics of the Po Valley (Bresciani and Perotti 2014). In fact, the plateau is located in correspondence with the partially buried anticline of Romanengo. Such geological structure gave rise to the lifting of the sediments overlying it and consisting mainly of Pleistocene fluvial sediments. Additionally, the most superficial part of the sedimentary cover consists of silty sediments, which can be interpreted as loess (Cremaschi 1987). The Pianalto di Romanengo after the Last Glacial Maximum, and especially in the early Holocene, underwent pedogenetic processes controlled mainly by the presence of suspended aquifers that promoted the weathering of the sedimentary sequence and the formation of specific pedogenetic horizons. In the western portion of the plateau, a paleosol is present: it developed into a parent material consisting of superficial wind sediments. Moreover, several pedogenetic processes have affected the upper part of the fluvial deposit; the most significant processes acting therein were the development of strong hydromorphy and argillification (Casati et al. 1987; Bassi and Casati, 1989). These processes have contributed to shaping the pedostratigraphic units forming the geological record at Romanengo and forming characteristic buried soil horizons, such as the fragipan (evolved on the wind-blown material and is quite common along the Po Plain), and the petroplinthite horizon developed at the transition between aeolian sediments and the clay-rich fluvial deposits (Fig. 4A) (Casati et al. 1987; Bassi and Casati 1989). If in the western portion of the Pianalto di Romanengo these two soil horizons are clearly identifiable, in the eastern part of the plateau they are not very evident (Cremaschi 1987): fragipan is generally recognizable, with variable thicknesses, while petroplinthite did not form. In fact, the interface between the silty and clayey 


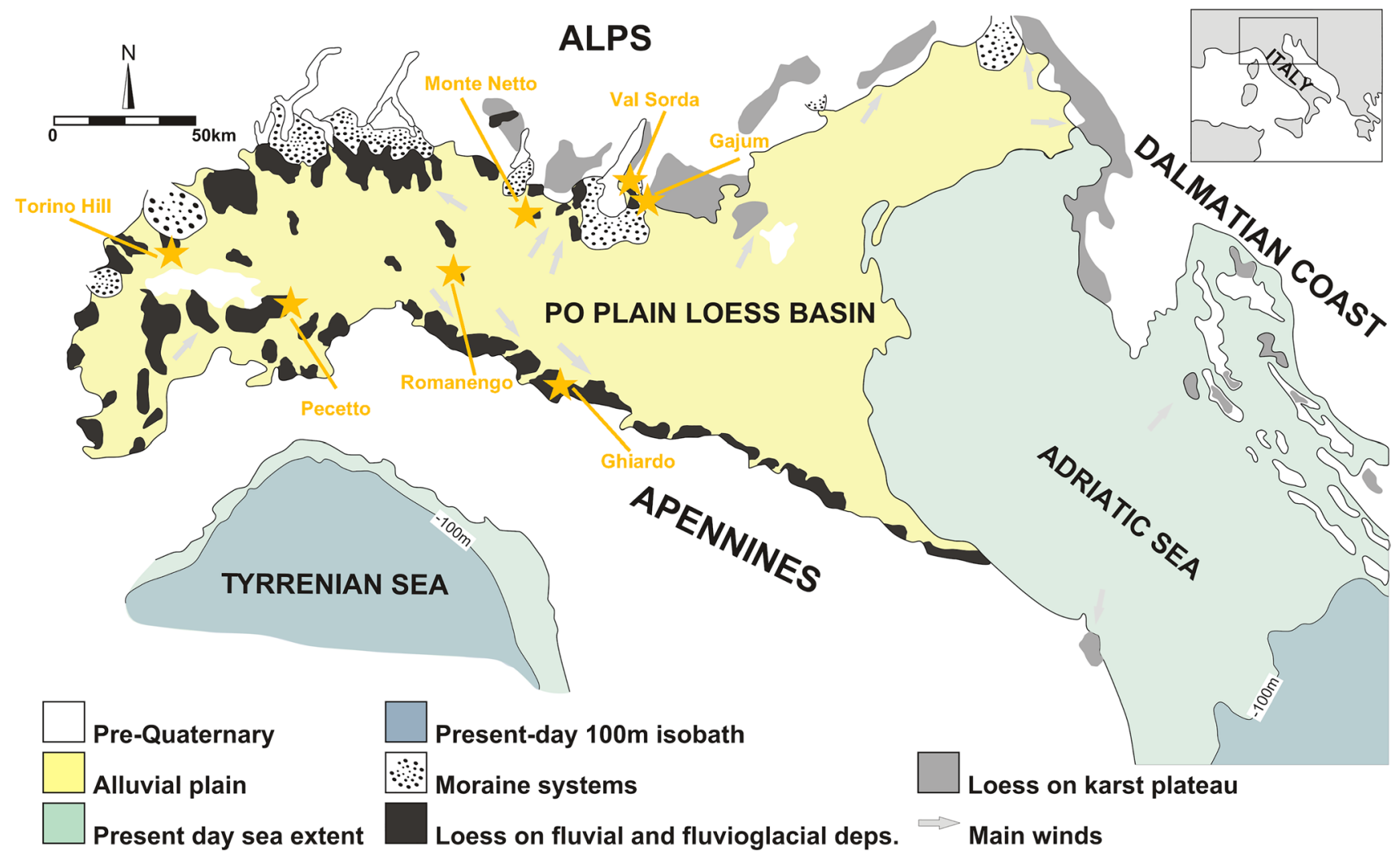

Fig. 1 Distribution of loess in the Po Plain of Italy (Zerboni et al. 2018; Lehmkuhl et al. 2021); stars indicate the position of the main localities cited in the text

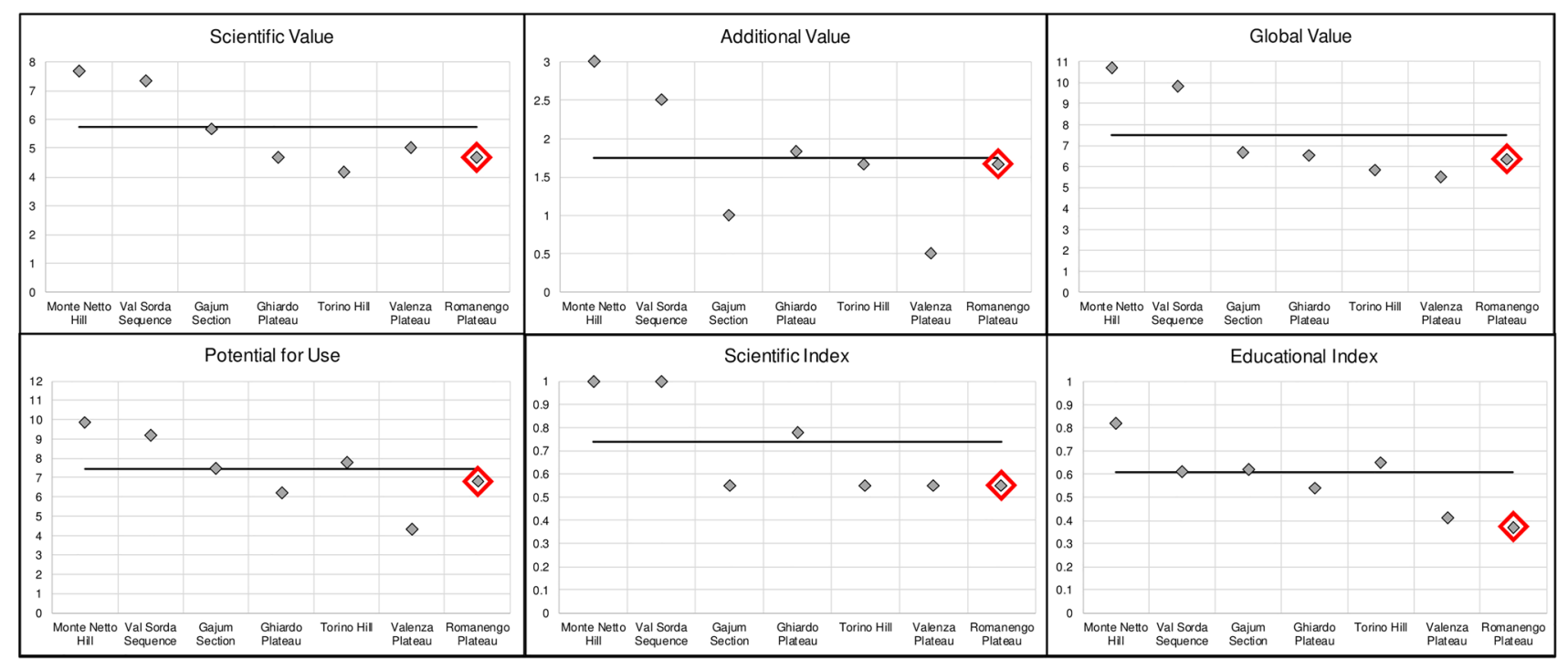

Fig. 2 Comparison among the sites in terms of macrovalues respect to the average for each category. Red diamonds are relative to the benchmark site (Romanengo Plateau)

units is marked only by the local occurrence of discontinuous concentrations of nodules and/or concretions rich in $\mathrm{Fe} /$ Mn oxyhydroxides.
The Pianalto di Romanengo Plateau is included in the Italian Geosite Inventory and in the province and region geosites lists. In the National Inventory, it is recognized 


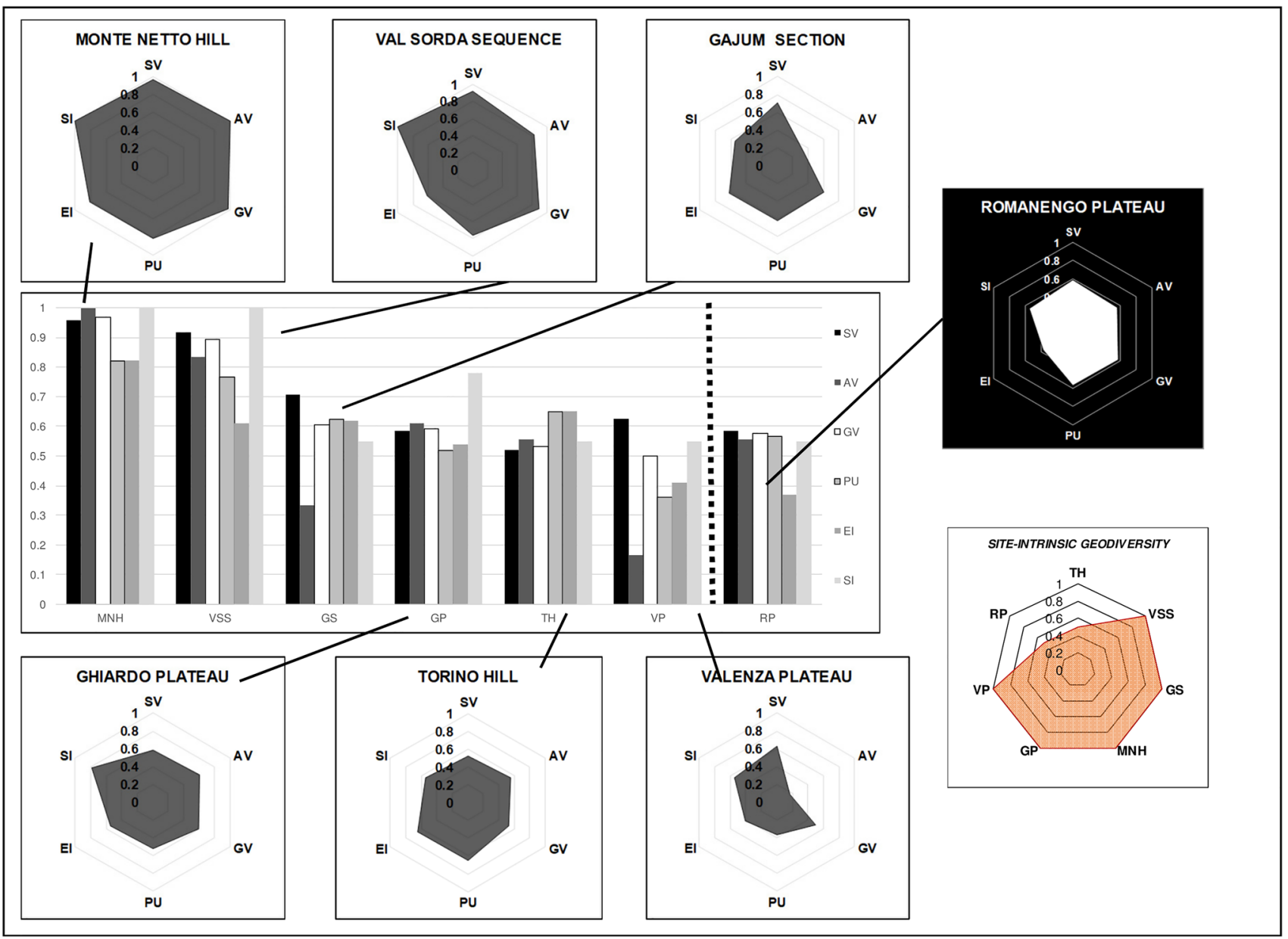

Fig. 3 Comparison among the sites in terms of macrovalues. The light orange radar graph shows the site-intrinsic Geodiversity of the assessed sites, quite always maximum (1) except for the Romanengo Plateau (RP) and Torino Hill (TH)

as geosite for its geomorphological (primary) and pedological (secondary) values, which are mostly related to the western part of the plateau. Also, the naturalistic value is considered of primary importance, while the cultural-educational-excursionist values are listed as secondary. Even if the conservation status of the site is indicated as good, it may undergo to natural and, more probably, intense human threats being it located in an intensely cultivated region.

Despite it is the only loess site included in the geosites list, it is characterized by values below the average of the other sites assessed in the present research. Low is in particular the Educational Index (0.37/1) and also the site intrinsic geodiversity (0.33/1) (Figs. 2 and 3). Notwithstanding the already activated use of both scientific and additional interests (i.e. use as geoheritage related interest or use of the additional interests; Suppl. Mat. B), and the presence of nearby services (Suppl. Mat. B), the Potential for Use is relatively low (6.81/12).

\section{The Ghiardo Plateau}

The belt of Early to Middle Pleistocene deformed terraces connecting the southern part of the Po River alluvial plain to the northernmost part of the Apennines (Cremaschi and Papani 1975) are covered by a thin but continuous body of loess (Cremaschi et al. 2015). Loess strata of the foot of the Apennines formed during the Upper Pleistocene and underwent several post-depositional processes, including strong pedogenesis and colluvial processes. Moreover, the remains of open-air campsite left by Upper Palaeolithic hunters settling the whole region are widespread (Lenzi and Nenzioni 1996) (i.e. cultural value; Suppl. Mat. A). Among the others, the most important localities correspond to the loess outcropping on the Ghiardo Plateau; beside the importance related to the deposition of wind-blown silt, the Ghiardo section preserves evidence of specific soil-forming processes and a major Mousterian archaeological site excavated in the 
Fig. 4 Field pictures and interpretation of deposits of the $\mathbf{A}$ Romanengo Plateau, B Ghiardo Plateau, and $\mathbf{C}$ Pecetto di Valenza loess sequences. In (B), the dotted line represents the mukkara/gilgai microrelief with formation of $\mathrm{Mn} / \mathrm{Fe}$ concretions
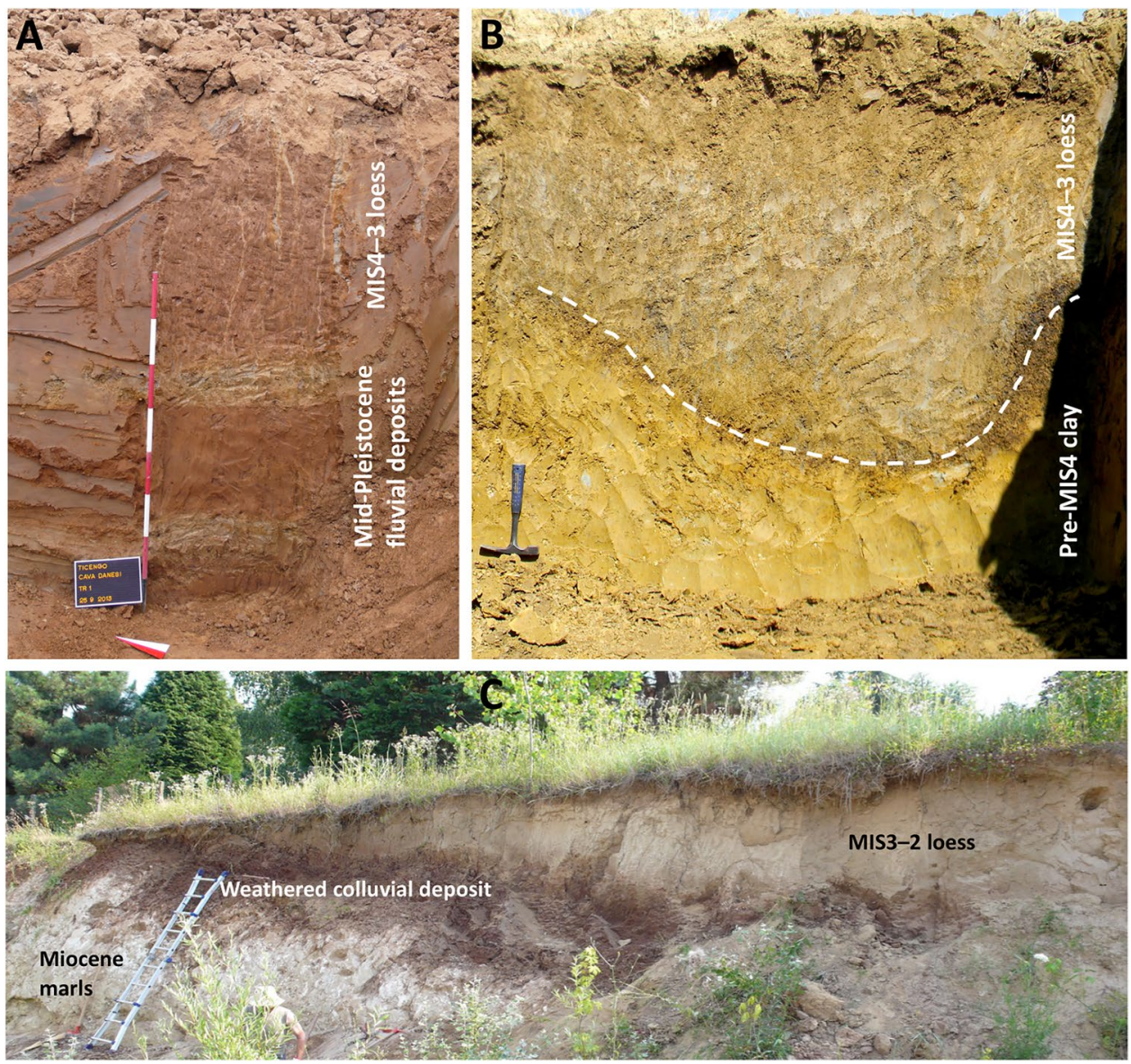

1980s of the twentieth century (Cremaschi and Christopher 1984; Cremaschi et al. 2015, 2016).

In the Ghiardo area, loess sedimentation occurred during cold and arid glacial periods between $\sim 70-35 \mathrm{ky}$ BP. The loess body cover a sequence of lacustrine clay weathered and pedoturbated into a hydromorphic soil with a well preserved buried mukkara/gilgai microrelief. The loess sequence is also weathered into a buried soil showing strong clay illuviation, decarbonation, hydromorphy, and vertic features (Cremaschi et al. 2015). At the top of the gilgai microrelief, the intense frequentation of the area by Middle Palaeolithic hunt is preserved buried by wind silt. Archaeological evidence consists of flint artefacts and remains of fireplaces related to the exploitation of Mousterian hunters at the initial phases of loess deposition in the area (i.e., cultural value; Suppl. Mat. A). The top of the Ghiardo sequence consists, below the modern agricultural horizon (Ap), of an eluvial soil horizon (E) preserving Chalcolithic archaeological remains (Fig. 4B). Such E horizon is the result of the combined action of Holocene pedogenesis and human action. In fact, the formation of the topsoil was triggered by the large-scale deforestation and onset of agricultural activities occurred since the Chalcolithic period. At this time, massive wood clearance, through slash-and-burn practice, is well documented all along the southern margin of the Po Plain, in the alluvial deposits occurring at the base of the terraces covered by loess (Cremaschi and Nicosia 2012).

The Ghiardo Plateau is featured by values above the average (Fig. 2) concerning the Scientific Index (0.78/1) and the Additional Value (1.83/3), while the other values remain significantly below the average: Scientific Value (4.67/8), Global Value (6.65/11), and Educational Index (0.54/1). Despite the more favourable spatial access to the site, the Ghiardo plateau is also penalized for the Potential for Use (6.21/12), especially due to the low visibility of the site and the scarce promotion (i.e., use as geoheritage related interest or use of the additional interest; Suppl. Mat. B) and appealing (i.e., number of tourists; Suppl. Mat. B) of the area. It is, like the Gajum Section (see in the following paragraphs), generally quite aligned with the benchmark site (Figs. 2 and 3).

\section{The Valenza Plateau}

The hills of the Eastern Monferrato Arc are covered by loess, which occasionally preserves evidence of paleoseismicity occurred in Middle Pleistocene to Holocene times (Michetti et al. 2014) (i.e. representativeness of 
geological processes; Suppl. Mat. A). Among the others, the Pecetto loess sequence on the top of the Valenza Plateau has been recently investigated (Frigerio et al. 2017). From the bottom, the pedosedimentary sequence of Pecetto consists of Miocene marly bedrock weathered into a paleosol during MIS 7 or 5 interglacials, overlaid by a colluvial deposit weathered during MIS 5e (Fig. 4C). The upper part of the sequence consists of two subsequent loess strata showing different degrees of weathering; loess sedimentation occurred presumably in the MIS 3-2 interval (Frigerio et al. 2017). Paleosols interlayered to the loess formed during short Upper Pleistocene interstadials. Moreover, the sequence preserves evidence for earthquake surface displacement, recording at least two events of deformation induced by earthquake surface reverse faulting and warping. The Pecetto site indicates the interaction between the tectonically-induced surface deformation and the aeolian sedimentation (i.e. representativeness of geomorphological and paleogeomorhological processes and representativeness of geological processes; Suppl. Mat. A). Moreover, the sequence demonstrates the ability of loess deposits to preserve environmental evidence of past earthquakes, thus having relevant implications in the assessment of the seismic hazard in areas historically not hit by earthquakes (Frigerio et al. 2017).

The Valenza Plateau is always below the average value for all the attributes, and often below the benchmark site. The Additional value is particularly low (0.5/3) as well as the Potential for Use (4.32/12) that reflects the scarce promotion (i.e. use as geoheritage related interest or use of the additional interests; Suppl. Mat. B) and appealing (i.e. number of tourists; Suppl. Mat. B) of the area as well as the legal constraints (Suppl. Mat. B) due to the location in a private property (Fig. 2).

\section{The Torino Hill}

Capeder (1898) and Viglino and Capeder (1898) were among the first scholars to investigate the problem of silt deposits at the fringe of the Alps, and they identify a thick accumulation of silt in the vicinity of Torino. They interpreted the silt of the Torino Hill outcrop as loess (Fig. 5) and published some of the first papers on Italian loess (i.e. geohistorical importance; Suppl. Mat. A). After their pioneering intuition, many scholars investigated the loess sequence of the Torino Hill, and Forno $(1979,1990)$ offer a review on the distribution, formation, and chronology of the Quaternary deposits (including loess) identified along the Ivrea glacial amphitheater (Gianotti et al. 2015).

At Torino Hill, loess outcrops differ according to their position (Forno 1979). The deposition of loess is limited to a small area and accumulated on top of Neogene sediments (Forno 1990). Loess displays a discontinuous distribution and a widely varying thickness with the thickest outcrops (up to $6 \mathrm{~m}$ thick) located in the central sector of the hill. Toward southeast, loess becomes thinner and overlays alluvial clay and silts, whereas in the southern part of the hill and extensive cover of wind-blown sands, up to $8 \mathrm{~m}$ thick is present. All outcrops are interlayered by paleosols. Along the Torino Hill, the loess underwent surface processes and was heavily reworked by sheet flow on the steeper slopes and by channel flow in depressions (Forno 1990); this process resulted in the considerable distribution of the reworked loess.

The Torino Hill could be classified as evolving passive geomorphosite (sensu Pelfini and Bollati 2014), since vulnerable to natural processes different from the genetic ones (sensu Garcìa-Ortiz et al. 2014). This site is above the average value concerning the Potential for Use (7.78/12) and the Educational Index (0.65/1) (Fig. 2). It is in fact characterized by a relatively easy access (i.e., spatial accessibility; Suppl. Mat. B), and it is located in an area where services
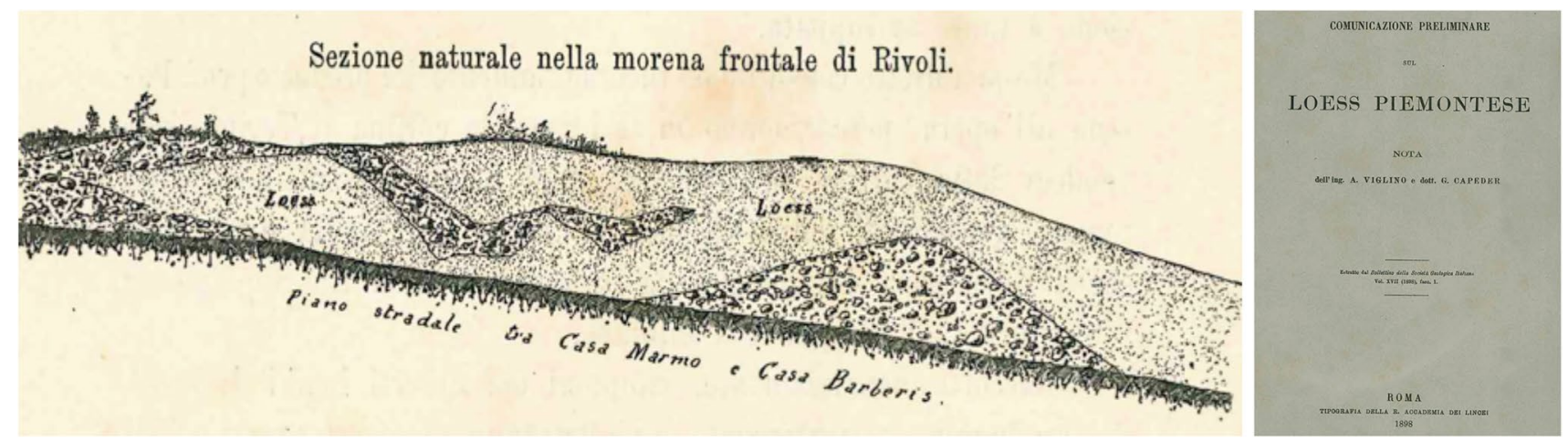

Fig. 5 The representation of the loess sequence of the Torino Hill by Viglino and Capeder (1898), which is among the first papers dedicated to Italian loess 
are located nearby. Respect to the benchmark site, apart from the values for which the Torino Hill is above the average, for the other values, it is slightly below or equal to it.

\section{The Val Sorda Sequence}

Among the loess sequences of Northern Italy, the Val Sorda has a special position, because it caught — as in the case of the Torino Hill - the interest of scholars since the beginning of Quaternary research in Italy (i.e., geohistorical importance; see Suppl. Mat. A). The Val Sorda loess sequence is located along a canyon at the eastern shores of the Garda Lake and lies among the Upper Pleistocene moraines of the Garda glacial amphitheater. The Val Sorda canyon was initially explored by local geologists (Nicolis 1899); soon after, also Penck and Brueckner (1909) investigated the sections when they decided to study the glacial systems at the southern fringe of the Alps. After World War II, the systematic investigation on the Garda Lake glacial system lead Venzo (1957, 1961) and Mancini (1960) to study the loess sequence of the Val Sorda; more recently, Cremaschi (1987, 1990) and Ferraro (2002, Ferraro et al.,
2004) performed a plethora of analyses and dating on the loess sequence. From a theoretical point of view, the relevance of the Val Sorda loess sequence (i.e., representativeness of geomorphological and palaeogeomorphological processes; Suppl. Mat. A) depends on (i) its thickness (up to $5 \mathrm{~m}$ ); (ii) the key position between the Garda Lake and Adige River moraine systems; (iii) the preservation of the original, syngenetic, and pedological characteristics; and (iv) the duration of sedimentation covering a long cycle during two subsequent Pleistocene glacials.

The loess outcrop along a narrow canyon cut at the western margin of the dip slope of the Monte Moscal monocline; several ridges of the Garda Lake glacial system surround it. The most spectacular outcrop along the Val Sorda canyon is the Torrion (that means "big tower" in local slang) locality (Fig. 6A). Therein, the loess body is embedded between two glacial deposits (Fig. 6A, B), belonging respectively to the last and penultimate glacial advances. The lowermost glacial deposit has been attributed to a pre-MIS 5e glacial advance (MIS 6) because its top is heavily weathered into a red, clay-rich palaeosoil. The loess sequence has been dated with a multiple approach using the radiocarbon, OSL and

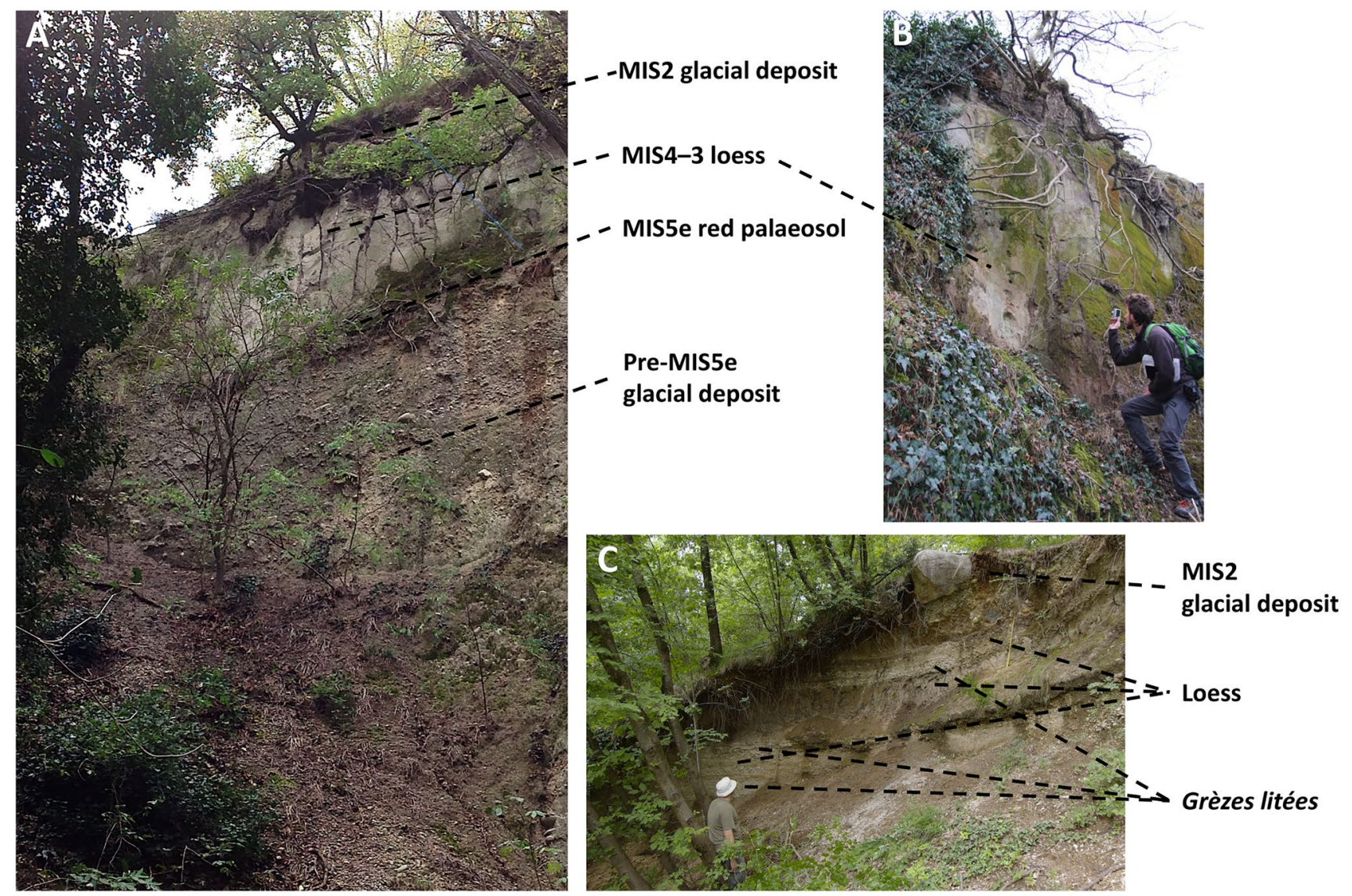

Fig. 6 Field pictures and interpretation of deposits of the Val Sorda $(\mathbf{A}, \mathbf{B})$ and Gajum $(\mathbf{C})$ sections. $(\mathbf{A})$ is the so-called Torrion, (B) is a detail of the Val Sorda loess sequence 
IRSL methods between $\sim 75 \mathrm{ky} \mathrm{BP}$ and the LGM (covering the time span MIS 4-2). Loess is interlayered by chernozemtype paleosols suggesting the interplay between increased and decreased wind activity (Cremaschi 1987). At the top of the sequence, between the loess and the MIS 2 glacial deposit, an 80 -cm-thick sequence of recycled loess is present, organized in decantation laminae formed in a proglacial lake environment and then deformed by glaciotectonic at the apex of the LGM.

The site is undergoing huge hillslope and fluvial erosion, and also in this case the vulnerability of the site to natural processes different from the genetic ones allows to classify it as evolving passive geomorphosite. The Val Sorda sequence is above the average for all the macrovalues, except for the Educational Index (0.61/1), for which it is about on the average (Fig. 2). This site is ranked second in the evaluation process, and it is especially high for what concerns the Scientific Value (7.33/8) and Scientific Index (1/1). The Potential for Use $(9.2 / 12)$ is relatively high, due especially to the presence of services (Suppl. Mat. B), the high touristic frequentation of the area, and the presence of other geomorphosites in the surroundings (Suppl. Mat. B). Respect to the benchmark Romanengo Plateau, this site acquires always higher values (Fig. 2).

\section{The Gajum Section}

The Gajum Section (Fig. 6B) is not far from the Val Sorda site and belongs to the Upper Pleistocene Adige River glacial amphitheater; also in this case, the sequence is complex and includes more types of sediments related to specific sedimentary processes (i.e., site-intrinsic geodiversity; see Suppl. Mat. A). The sequence was deposited inside a karst sinkhole on the limestone bedrock of the Monte La Mesa Hill and discovered during the quarrying of the local limestone. The sequence was preserved from erosion because sheltered by the walls of the sinkhole and capped by a glacial diamicton. The stratigraphic sequence described at Gajum - up to $8 \mathrm{~m}$ thick - consists of a series of loess units interlayered with stratified slope deposit related to freeze-thaw action (grèzes litées; sensu Guillien 1962). Moreover, the sequence is buried by a till accreted during the LGM advance of the Adige River Glacier. Only two radiocarbon dating is available for the two uppermost loess layers of the sequence, dated respectively to $\sim 41 \mathrm{ky} \mathrm{BP}$ and $>42 \mathrm{ky} \mathrm{BP}$ (Cremaschi 1990). The oldest dating suggests that the loess at Gajum formed at least during the MIS 3 (maybe since MIS 4), whereas the uppermost contact of loess with the LGM diamicton indicates that sedimentation possibly lasted up to the MIS 2, substantially in accordance with the nearby Val Sorda sequence. Moreover, the existence of deeper loess strata may suggest wind sedimentation before MIS 4, likely in proximity of the penultimate glacial. The scientific value of this sequence is further increased by the occurrence in the uppermost loess strata of evidence of frost action in the form of foliations, prismatic structures, and ice-wedge casts. Cryogenic loess disturbance features suggest the occurrence of a periglacial environment with seasonally frozen topsoil and represent one of the southernmost appearances in Europe of Pleistocene ice-wedge casts loess deposits (i.e. representativeness of geomorphological and palaeogeomorphological processes; Suppl. Mat. A).

The Gajum Section is a not high-valued site (Fig. 2): it is nearby the average for the Scientific Value (5.66/8), Potential for Use (7.48/12) and Educational Index (0.62/1), while it is, sometimes also significantly, below in terms of Additional Value (1/3), Global Value (6.66/11), and Scientific Index $(0.55 / 1)$. Concerning the Potential for Use, it is determined by the not-yet started promotion of any type of values (i.e., use as geoheritage related interest or use of the additional interest; Suppl. Mat. B) and the relatively difficult spatial accessibility to the site (Suppl. Mat. B). In general, the Gajum Section is quite aligned to the benchmark site values.

\section{The Monte Netto Hill}

In the central sector of the Po Plain (northern Italy), several isolated hills exist, corresponding to the top of Late Quaternary anticlines related to compressive tectonic. Isolated hills are distributed from the fringe of the Southern Alps up to the central Po Plain, and their tectonic origin was initially proposed by Desio, 1965). The emergence of these hills is due to the Late Quaternary growing of a fold related to a fault system composed of a main south-vergent forethrust and an associated high-angle backthrust (Livio et al., 2009; Livio et al., 2014; Livio et al., 2020) (i.e., representativeness of geological processes; Suppl. Mat. A).

The Monte Netto Hill is rectangular in shape, $5 \mathrm{~km}$ long and $2 \mathrm{~km}$ wide, and standing about $30 \mathrm{~m}$ above the surrounding alluvial plain. The top of the hill exposes a gently folded sequence of Lower to Middle Pleistocene fluvial sediments, whereas Middle to Upper Pleistocene fluvial sediments onlap the hill on both sides (Livio et al. 2009). At the top of the Monte Netto Hill, a moderately weathered, Upper Pleistocene loess deposit, overlying a deeply weathered red paleosol, was described by Cremaschi (1987). More recently, in correspondence of a quarry of clay for bricks, a thick and complex loess-paleosol sequence, resting upon fluvial/ fluvioglacial deposits, was investigated (Livio et al. 2009; Zerboni et al. 2015). The sequence is folded and corresponds to the top of an active anticline (Fig. 7A); as a consequence, at the top of anticline a highly rubified paleosol is present, regarded as a polygenetic soil or a vetusol (sensu Cremaschi 1987; Cremaschi et al. 2018), developed near the surface since the Middle Pleistocene. On the slope of the anticline, the pedosequence is more complex (Fig. 7B, C). The lower 


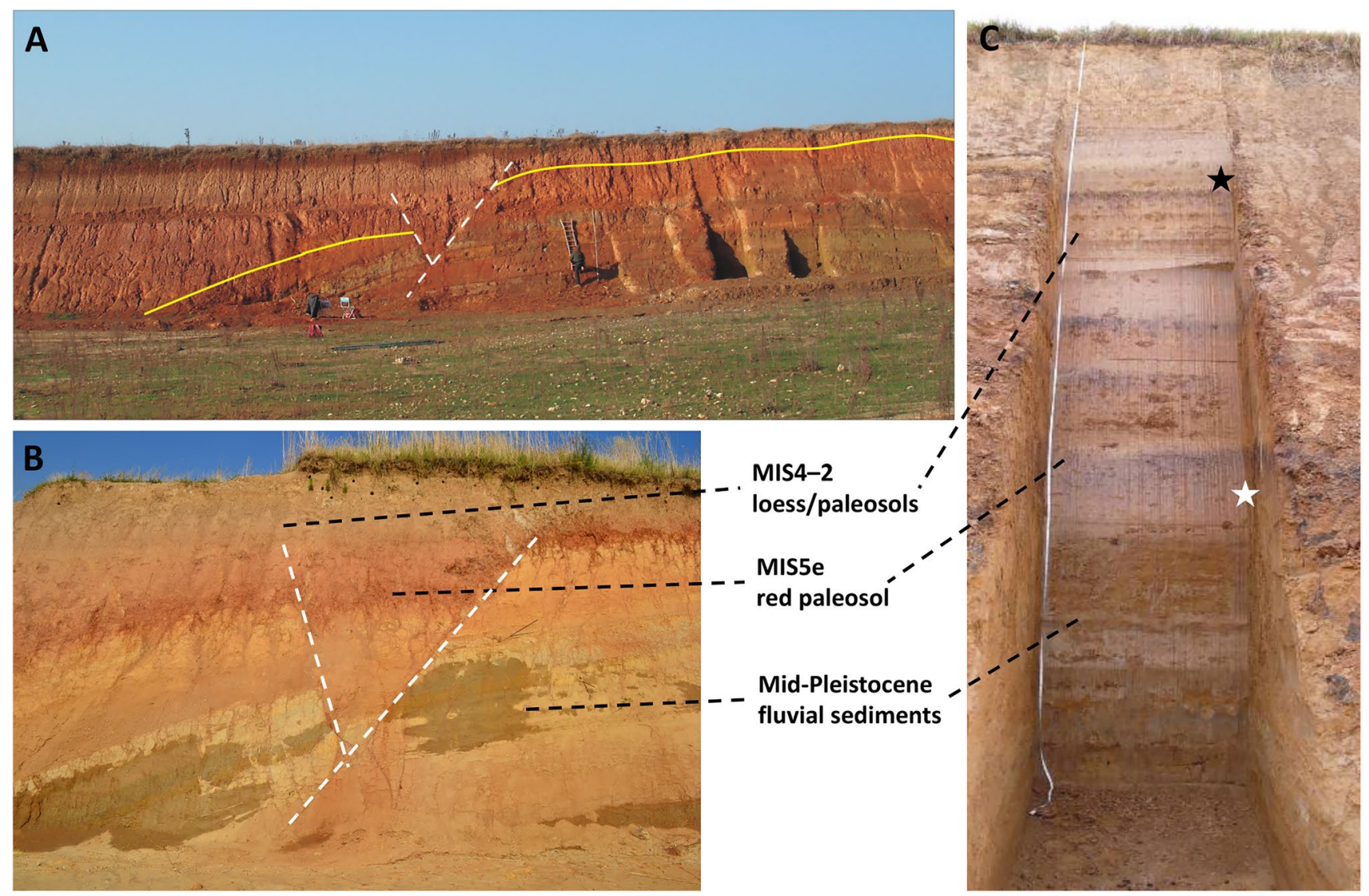

Fig. 7 The loess sequence of the Monte Netto Hill, the top of the anticline is on the right. (A) The quarry on top of the hill exposing the complex loess/paleosols sequence; the yellow line marks the transition from fluvial (below) to wind (above) sediments, the white lines suggest the position of the graben structure. (B) A detail of the

part of the section includes highly deformed fluvial and fluvioglacial deposits (Middle Pleistocene age), capped by a thick red paleosoil, followed by a 2- to 5 -m-thick loesspaleosol sequence. The latter pedosedimentary sequence consists of several loess layers topped by $\mathrm{Bt}$ soil horizons showing different degrees of pedogenesis. The loess formed between MIS 4-2 and pedogenesis (including decalcification, clay illuviation, oxides formation, and pedoplasmation) likely occurred during interstadials. The degree of weathering of buried Bt horizons decreases from the bottom of the sequence toward the top, suggesting a progressive decrease in the intensity of pedogenesis across the Upper Pleistocene. The original, gently wavy topography of the top of Monte Netto (controlled by the seismotectonic evolution of the hill) regulated the accumulation of loess; this and subsequent geomorphological and pedogenetic processes tuned the formation of a proper loess landscape.

Two more elements increase the value of the Monte Netto Hill loess sequence: it preserves the evidence of environmental effects of strong local earthquakes occurred in the Late graben structure. (C) the reference stratigraphic sequence at Monte Netto. The interpretation of deposits is reported in (B) and $(\mathbf{C})$; the black (late Mousterian) and white (lithics on quartzite cobbles) stars indicate the position of archaeological findings (for details see Delpiano et al. 2019)

Quaternary (i.e., representativeness of geological processes; Suppl. Mat. A) and archaeological findings corresponding to the remains of a Middle Palaeolithic open-air campsite (i.e., cultural value; Suppl. Mat. A). According to Livio et al. (2009, 2014, 2020), evidence of earthquakes includes coseismic surface faulting, liquefaction features, vertical fissures related to deformational stress and interpreted as seismipedoturbations, and several bending-moment faults at the culmination of the anticline. The latter creates a main graben structure and other secondary extensional structures displacing the loess-paleosoil sequence. Along the loess-palaeosoil sequence, frequentations by Mousterian Neanderthal groups are attested at two different times (Cremaschi 1974; Delpiano et al. 2019). The most consistent human frequentation is associated to loess accumulation dated to $\sim 44 \mathrm{ky}$ BP. This evidence testifies the sporadic frequentation of marginal open areas during the cold and arid climate of the MIS 3.

At the top of other isolated hills of the Po Plain, loess is well preserved, and the geomorphological context is similar to the one described at Monte Netto. For instance, in the 
southern sector of the central Po Plain, loess was described on the Romanengo Plateau at the top of deformed fluvial sediments (Cremaschi, 1987), and more complex loesspaleosol sequences have been described at the top of the San Colombano Hill, developed above one of the buried frontal arcs of the Northern Apennine thrust belt (Zuffetti et al. 2018).

In the regional inventory of geosites, the Monte Netto Hill is classified in the structural geology category. It obtained the highest scores respect to the other sites, in each category of macrovalues: Scientific Value (7.67/8), Additional Value (3/3), and Global Value (10.67/11). Also, the Scientific Index (1/1) and the Educational Index (0.82/1) are very high (Figs. 2 and 3), and, consequently, it is always above the average values and the benchmark site values. Concerning the Potential for Use $(9.84 / 12)$ is high, but it is penalized due to the location of the site within a private quarry, implying the request of access to the owners (i.e., legal constraints; Suppl. Mat. B). This penalty could be solved through the interaction with the local owners that have just demonstrated to be collaborative during the scientific inspections.

\section{Discussion}

In order to summarize all the aspects herein discussed, in the following parts, we will examine data on the geodiversity of loess sequences in the Po Plain Loess Basin (Fig. 3), and then the possibility of promoting loess outcrops as geoheritage sites. In Fig. 8, a theoretical scheme describing the concepts of values, threats, and the opportunities for geoconservation or promotion practices for loess geoheritage sites is proposed, integrating the inputs from the literature with the fresh ones emerging from our data.

\section{Geodiversity Recorded by Loess Sequences in the Po Plain Loess Basin}

Even if the attention of the scientific communities has been mainly addressed towards the quantitative evaluation of geomorphosites, the method applied in this study allows evaluating geoheritage sites with a specific focus on geodiversity, considering thus their geological and geomorphological representativeness. In previous works (Table 1), the geodiversity parameter has not yet been considered in-depth.

At the regional scale, geodiversity could have a two-fold perspective, including geodiversity respect to external areas (or sites) (i.e. extrinsic geodiversity sensu Panizza 2001 and Bollati et al. 2016) or respect to the site-inward type geodiversity (i.e. site intrinsic geodiversity sensu Panizza 2001 and Bollati et al. 2016). According to the results obtained by the selected loess outcrops as potential geoheritage sites, for what concerns the attribute of site-intrinsic geodiversity (Fig. 3) and contributing to the Scientific Value (Fig. 8), almost all the assessed loess sequences reached the maximum value (1). This means the coexistence of different lithologies and/or deposits and landforms. The only exceptions are represented by the Romanengo Plateau (the benchmark

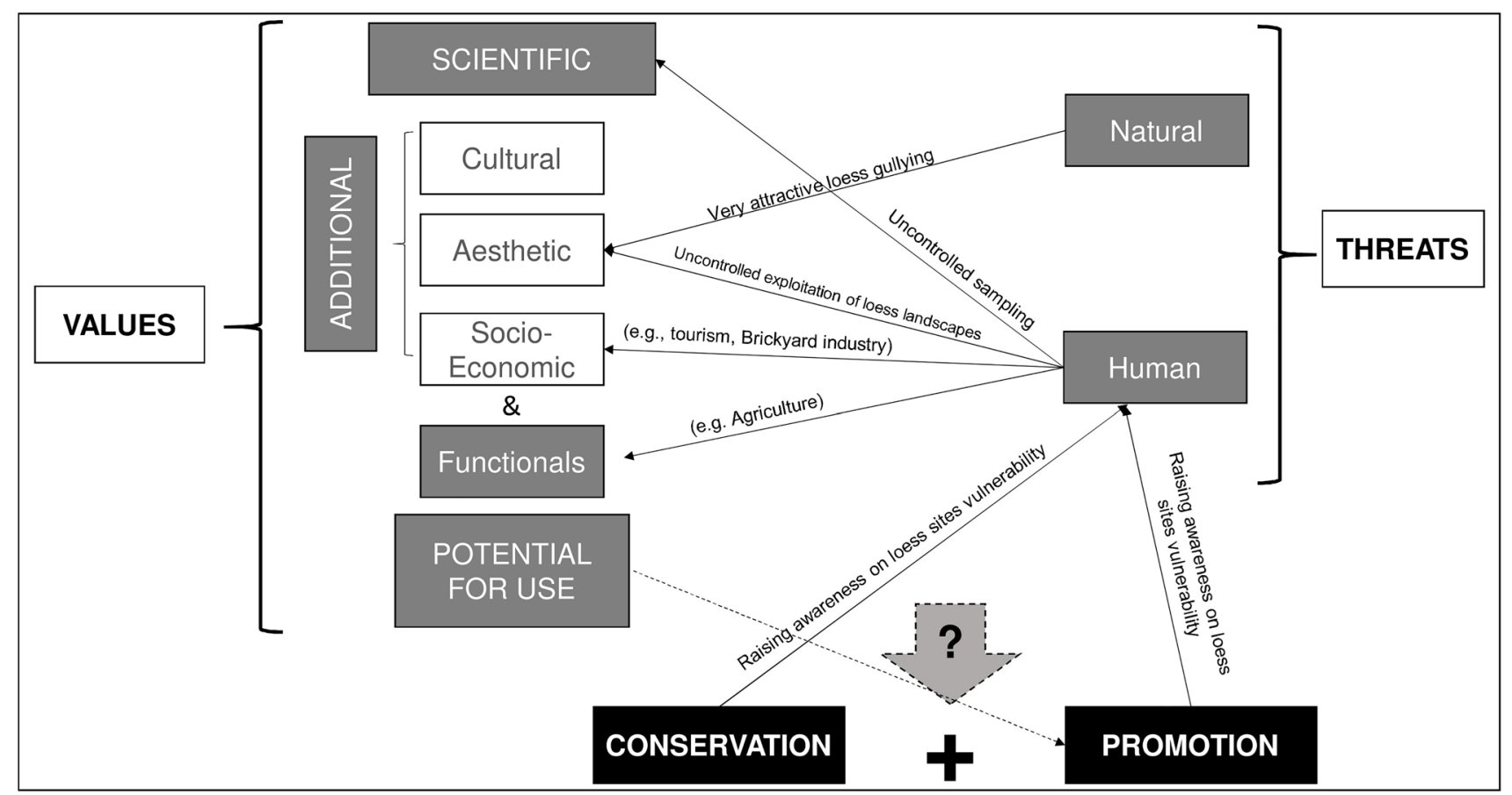

Fig. 8 Conceptual scheme linking values, threats, and possible effects derived from geoconservation and promotion practices 
site) and the Torino Hill. Even if the evaluated sites, that are scattered within the Po Plain, do not display substantial differences, they can be counted among the sites with a relevant richness respect to other types of geosites in the region, especially for the mixture of the geomorphological and geological features related to specific regional settings. Furthermore, quantitative comparative analysis among sets of sites confirms this data.

In general, considered sites display very high values in terms of geodiversity and scientific importance, as already observed at other loess sites (Lukić et al. 2009; Višnić et al. 2016). In fact, all the considered loess outcrops are key sites to disclose the late Quaternary evolution of the Po Plain and the interplay between fluvial, glacial, and wind sedimentary processes and pedogenesis. From one hand, loess from the Po Plain is a typical example of Mediterranean loess (sensu Lehmkuhl et al. 2021), which means that loess formed under cold and arid conditions, but interlayered paleosols are exceptional archives recording interstadial/interglacial warm conditions promoting various kinds of pedogenetic processes (i.e. representativeness of geomorphological and paleogeomorhological processes; Suppl. Mat. A). The Val Sorda and the Monte Netto Hill sequences, for instance, are the thickest in the region and covers the MIS 4-2 period recording also short-timed intervals of decreased wind strength and environmental aridity. In this perspective, they are among the rarest occurrence at regional scale (i.e. rarity; Suppl. Mat. A) and are the top ranked sites in the analysed cluster. Most of the sequences, and especially the thinner ones, underwent strong pedogenesis after the termination of the Last Glacial Maximum, as in the case of the Ghiardo Plateau. Such sites recorded the warm and wet environmental conditions that dominated the Mediterranean basin during the Early and Middle Holocene. On the other hand, loess outcrops in northern Italy have other scientific values that allow increasing the site-intrinsic geodiversity, because they record the historical seismicity and, more in general, the high dynamicity of the Alpine foreland (i.e. representativeness of geological processes; Suppl. Mat. A). The Monte Netto Hill, Valenza and Romanengo plateaus formed thanks to the tectonic deformation that created sedimentary traps for wind-blown particles. At Monte Netto Hill, for example, the continuous accumulation of wild blown silt during the MIS 4-2 interval permitted to record the occurrence of seismic shocks occurred in the Upper Pleistocene, thus suggesting major implications for the (palaeo-)seismicity of the area.

An additional value (Fig. 8) of loess in the Po Plain is human exploitation (i.e. cultural value; Suppl. Mat. A). In fact, many sequences preserve evidence of Upper Pleistocene human frequentation, when wind sedimentation was active. The archaeological excavation at Ghiardo Plateau disclosed the complexity of the Mousterian campsites and the exploitation of the Po Plain landscape during cold and arid phases of the Upper Pleistocene by hunter groups. The archaeological findings from the Monte Netto Hill, although a proper archaeological excavation is still lacking, preserve evidence for high mobility between the Prealps and the Po Plain among late Mousterian hunters.

Considering all these features, despite most of the sites $(70 \%)$ assessed in the framework of this research gained values higher than the benchmark site (i.e. Romanengo Plateau), the only one included in the National Inventory of Geosites, almost all the sites herein evaluated are, for sure, worth to be proposed for the inclusion in the National Inventory of Geosites, a step towards their protection and promotion too (Vasiljević et al. 2011b). This fact may push to add other loess sites to the National Inventory of Geosites.

\section{Promotion or Conservation of Loess Outcrops as Geoheritage Sites?}

The loess geoheritage sites display all the 3 features discussed by Coratza and Hoblea (2018) as distinctive of geomorphological heritage sites: they are (i) spectacular, (ii) multi-scaled, and (iii) dynamic. Considering the latter feature, they are mainly evolving passive geomorphosites (sensu Pelfini and Bollati, 2014) undergoing modeling due to natural agents different from the genetic one. Due to their vulnerability (sensu Garcìa-Ortiz et al. 2014) and rarity, they should be protected from both natural and human threats (Fig. 8) (Vasiljević et al. 2011a; 2014; Wang et al. 2019). Vasiljević et al. (2014), in relation to other areas of Europe, warn about the potential loss of loess sections, often featured by low thickness and which, if affected by erosion, can be totally dismantled, thus losing their value as record of past environmental settings. The dynamicity affecting loess geoheritage sites thus requires a continuous monitoring and periodical re-evaluations, in order to check the potential gain/loss of Global Value or Potential for Use of a site (Pelfini and Bollati, 2014). Despite the attention and warning about vulnerability and rarity of loess outcrops, some strategies can support their inclusion among geoheritage sites. First, to increase the awareness among the general public about these sites and their potential vulnerability is mandatory, and this can be accomplished using sites themselves as a tool to defeat some kinds of human threats listed in Table 2. The important role of loess in educational applications is highlighted by Zgłobicki et al. (2015), who investigated the general knowledge of people about the formation of gullies in loess deposits and how this aspect of loess outcrops should be explained to the general public, because it is relevant in terms of ongoing erosion, related to hazards and potential risks. Their aim is to make people familiar with the concept of soil erosion, which is mostly triggered by human impact. 
Using the approach proposed by Reynard et al. (2007), it is clear how a quantitative assessment of geoheritage sites like the ones here applied constitutes the basis for the discrimination between very highly vulnerable sites with high scientific value, which could be considered for geoconservation strategies, and sites that are scientifically valued but less vulnerable. The latter kind of sites can be promoted and potentially used (Baadi et al. 2020). Martínez-Graña et al. (2013) underline how a quantitative assessment aimed at selecting geoheritage sites is mandatory for conservation versus promotion purposes, because this allows highlighting selected sites as hotspots of geodiversity into a wider regional geological framework and favouring geoconservation initiatives.

In particular, the option of promotion depends on the possibility of working in collaboration with local authorities and/or private owners. This is, for instance, the case of Monte Netto Hill, where the owner of the quarry preserved the most representative part of the loess outcrop and added panels to explain the significance of the site to a general audience. In this case, the sustainable development of activities deriving from the collaboration with managers and local authorities is fundamental (Vasiljević et al. 2011a; 2014; Vujicić et al. 2011). In general terms, loess sequences suffer great vulnerability due to weathering and erosion. Their protection may require specific onsite facilities, including the sheltering of outcrops against atmospheric agents, cleaning surfaces to increase visibility, and consolidating them. In order to prevent disaggregation, chemical products can be employed (e.g. TEOS — based treatment tetraethyl orthosilicate), even if presenting some criticisms undergoing analysis for improvement (e.g. Franzoni et al. 2015). Moreover, a continuous monitoring should be planned to prevent plant growth, and excavation of burrowing animals.

Since the analysed loess sequences in the Po Plain Loess Basin are represented mainly by single outcrops, a "loess landscape" approach would be difficult. On the contrary, the same approach would be suitable in the case of the Danubian Basin or along the Chinese Loess Plateau and would increase benefits thanks to the scenic value of such landscapes (e.g. impressive gullies). In our case study, characterized by a scattered distribution and rarity of well-developed sequences, the specific approach proposed by Vasiljević et al. (2011b) could be applied. In order to provide to loess sites at the same time visibility and protection, an important action is to label them as official geosites at international (or at least national) level. As mentioned, in Italy a National Inventory of Geosites is managed by ISPRA, and geosites are also identified on a more local scale by regional authorities according to different criteria. A possible strategy would include two actions: (i) to identify each potential loess geosite through the proposed methodology, considering as a benchmark a site already inserted in the National Inventory of Geosites, and promote it for the inclusion in the national (and regional) database(s), and (ii) to establish a network of loess sites (loess geotourism localities) through thematic routes across a region and possibly integrating single outcrops into experiences showing the significance of the Mediterranean loess landscape. This last option was suggested also by other authors (Warowna et al. 2016). The latter could be potentially applicable to the Po Plain, imagining a sort of "diffuse geopark", even with all the limitations reported by Vasiljević et al. (2011b). The integration into local touristic itineraries between loess geosites and other types of geosites - for instance, those related to the same scientific topics preserved in loess sequences (palaeoclimatology, palaeoseismology, archaeology) or, at the regional scale, those showing Quaternary evolution of the Po Plain - is a further opportunity of promotion, which can increase the geodiversity value and the attractiveness of the diffuse geopark. For instance, in the specific cases of Torino Hill, Gajum, and Val Sorda outcrops, the potential evaluated sites are connected to other relevant features, such as the Upper Pleistocene glacial amphitheatres formed by piedmont glaciers. Glacial amphitheatres are a specific remnant of Pleistocene glacial phases of northern Italy and are distributed at the mouth of the major valleys descending from the Alps. In these latter cases, loess sites would contribute to the enhancement of the geodiversity of glacial amphitheatres, already recognised as relevant geoheritage elements (i.e. for the Rivoli-Avigliana glacial amphitheatre and the Torino Hill; Lucchesi et al., 2015). Furthermore, a recent assessment on diversified geosites including loess outcrops confirmed the increased suitability for tourism of specific regions in terms of their main additional values (Vujičić, et al. 2011), further supporting natural heritage protection.

Side by side to field experiences, representing a powerful tool towards Earth Sciences education (e.g. Pelfini et al. 2016), the most recent technologies provide innovative opportunities (Cayla 2014; Perotti et al. 2020). They can be applied to show the current conditions of geoheritage features, as much as the past conditions and evolution. In the first case, referring to the current distribution and settings of loess outcrops in the Po Plain, it could be possible to create virtual geo-tours using open-source software (e.g. Google Earth ${ }^{\mathrm{TM}}$, Google Maps ${ }^{\mathrm{TM}}$ ) that can show in advance localities, also with 3D views, to the potential visitors (e.g. Perotti et al. 2020). Recent proposals show how to overlap geoheritage sites to thematic maps (e.g. Pelfini et al., 2020) realizing Google Earth ${ }^{\mathrm{TM}}$ flights (e.g. Martínez-Graña et al. 2013) to contextualize the information at the regional scale. The traditional panels on site could be, in this way, replaced, or also accompanied, by virtual cards of each site on thematic websites or apps designed for different kinds of devices. An additional opportunity is represented by the realization of 3D models of outcrops, a 
type of view especially appealing to younger generations (e.g. Santos et al., 2018). Additional and more dynamic information could be uploaded on dedicated websites, including the proposed multimedia products.

Concerning the overview on past settings, virtual reconstructions of pristine landscapes including the human frequentation of the area could be a strategic solution helping in raising the attractiveness of each site. Some relevant examples were recently proposed for Italian (Pietroni et al. 2013) and world (Lercari et al. 2013) landscapes. The additional opportunity of developing games for cultural heritage promotion was recently discussed by Lercari et al. (2013) and Mortara et al. (2014). The gamification could enrich the experience of present and ancient landscapes exploration (Pelfini et al. 2016). For instance, Mortara et al. (2014) analysed the opportunities offered to different categories of users (museum visitors, school students, privates), based on different primary learning objectives (e.g. artistic/archaeological/architectural/natural heritage awareness, historical reconstruction) and game genres (e.g. strategy, simulation, adventure, action, quiz, and puzzle).

Apart from the information on the site aspect, its genesis, and meaning in the framework of the regional setting, explanations of natural and human threats could be added, in order to raise awareness in different generations of people regarding the promotion through geoconservation of such sites. Besides representing an attractive opportunity for young generations, virtual approaches could help in presenting sites with their points of fragility before the fieldtrip take place. This would help promoting a sustainable approach to fragile geosites during visiting the geopark.

\section{Conclusions}

Despite often disregarded in the international panorama, loess outcrops of the Po Plain Loess Basin demonstrated to be valuable geoheritage sites and meaningful in terms of cultural value. They allow, in fact, reconstructing glacial and interglacial cycles; they testify the paleoseismicity of the Alpine and Apennine forelands, thus featuring a high site-intrinsic geodiversity. They are also evolving passive geomorphosites, a feature to be considered in the framework of geoconservation versus promotion. The quantitative assessment of a series of sites respect to a benchmark site, included in the National Inventory of Geosites, served as detecting how the greatest part of the evaluated loess outcrops could be worth to be inserted in this list, and they should undergo attention being potentially vulnerable. They could be promoted through different kinds of virtual experiences (e.g. virtual tours, 3D modeling, and gamification) contextualized in a sort of "diffuse geopark" representing Mediterranean loess landscapes and allowing to visit it by remote, favouring both promotion and geoconservation, by raising awareness in the general public on the relevance and vulnerability of such loess sites for reconstructing the natural and human-related history of our planet.

Supplementary Information The online version contains supplementary material available at https://doi.org/10.1007/s12371-021-00596-2.

Acknowledgements This research has been carried out within the activities of the GEODUST International Focus Group of the TERPRO Commission of INQUA. We acknowledge Fornaci Laterizi Danesi S.p.A. for allowing us working in the area of their quarries at Monte Netto and Pianalto di Romanengo. We also thank prof. M. Pelfini for the critical review of the manuscript, and many people that supported the investigation on loess: M. Cremaschi, A.M. Michetti, R. Amit, F. Livio, L. Trombino, C. Frigerio, G.S. Mariani, L. Bonadeo, O. Crouvi, A. Perego.

Author contribution I.M. Bollati prepared the manuscript, analysed the role of loess outcrops in the geoheritage framework, performed the quantitatively analysis of loess sites, and applied the methodology she had elaborated before. A. Zerboni provided data on study cases and collaborated to the quantitative evaluation of each site, to the discussion and in writing the manuscript.

Funding Open access funding provided by Università degli Studi di Milano within the CRUI-CARE Agreement. This study is financially supported by the Università degli Studi di Milano Progetto Linea 2 (2017) and CTE_NAZPR19AZERB_01 entrusted to AZ and Progetto Linea $2(2018,2019)$ entrusted to IMB. Part of this study is supported by the Ministry of Education, University and Research (MIUR), Italy, through the project 'Dipartimenti di Eccellenza 2018-2022' (DECC18_020_DIP) awarded to the Dipartimento di Scienze della Terra 'A. Desio' of the University of Milano.

Data availability Data available upon request.

Code availability Microsoft Office Access 2016 (Licensed to University of Milan).

\section{Declarations}

Conflicts of interest The authors declare no competing interests.

Open Access This article is licensed under a Creative Commons Attribution 4.0 International License, which permits use, sharing, adaptation, distribution and reproduction in any medium or format, as long as you give appropriate credit to the original author(s) and the source, provide a link to the Creative Commons licence, and indicate if changes were made. The images or other third party material in this article are included in the article's Creative Commons licence, unless indicated otherwise in a credit line to the material. If material is not included in the article's Creative Commons licence and your intended use is not permitted by statutory regulation or exceeds the permitted use, you will need to obtain permission directly from the copyright holder. To view a copy of this licence, visit http://creativecommons.org/licenses/by/4.0/. 


\section{References}

Amit R, Zerboni A (2013) Report on the INQUA-AEOMED fieldtrip workshop 'reconsidering loess in Northern Italy' (Po Plain, 1-3 July 2013). AMQ - Alpine and Mediterranean Quaternary 26(2): pp. xi-xv.

Antoine P, Rousseau DD, Zöller L, Lang A, Munaut AV, Hatte C, Fontugne M (2001) High-resolution record of the last interglacial-glacial cycle in the Nussloch loess-palaeosol sequences, Upper Rhine Area. Germany Quaternary Int 76-77(1):211-229. https://doi.org/10.1016/S1040-6182(00)00104-X

Baadi K, Sabaoui A, Tekiout B (2020) Methodological proposal for assessment geosites: its application in Bou-Iblane Region (Middle Atlas, Morocco). Geoheritage 12(3):1-16. https://doi.org/10. 1007/s12371-020-00476-1

Badino F, Pini R, Ravazzi C, Margaritora D, Arrighi S, Bortolini E, Figus C, Giaccio B, Lugli F, Marciani G, Monegato G, Moroni A, Negrino F, Oxilia G, Peresani M, Romandini M, Ronchitelli A, Spinapolice EE, Zerboni A, Benazzi S (2020) An overview of Alpine and Mediterranean palaeogeography, terrestrial ecosystems and climate history during MIS 3 with focus on the Middle to Upper Palaeolithic transition. Quaternary Int 551:7-28. https:// doi.org/10.1016/j.quaint.2019.09.024

Bassi G, Casati E (1989) Contributo allo studio geomorfologico del Pianalto pleistocenico di Romanengo (CR). Pianura 2:57-64

Boukhchim N, Fraj TB, Reynard E (2018) Lateral and "VerticoLateral" Cave Dwellings in Haddej and Guermessa: Characteristic Geocultural Heritage of Southeast Tunisia. Geoheritage 10(4):575-590. https://doi.org/10.1007/s12371-017-0251-2

Bollati I, Leonelli G, Vezzola L, Pelfini M (2015) The role of Ecological Value in Geomorphosite assessment for the debris-covered Miage Glacier (Western Italian Alps) based on a review of 2.5 centuries of scientific study. Geoheritage 7(2):119-135. https:// doi.org/10.1007/s12371-014-0111-2

Bollati I, Fossati M, Zanoletti E, Zucali M, Magagna A, Pelfini M 2016 A methodological proposal for the assessment of cliffs equipped for climbing as a component of geoheritage and tools for Earth Science education: the case of the Verbano-Cusio-Ossola (Western Italian Alps). In Skourtsos E, Lister G (eds.), General Contributions, J Virtual Exp, Electronic Edition, Volume 49, paper 1, pp. $1-23$

Bollati I, Lenz BC, Zanoletti E, Pelfini M (2017) Geomorphological mapping for the valorization of the alpine environment. A methodological proposal tested in the Loana Valley (Sesia Val Grande Geopark, Western Italian Alps). J Mount Sci 14(6):1023-1038. https://doi.org/10.1007/s11629-017-4427-7

Bresciani I, Perotti CR (2014) An active deformation structure in the Po Plain (N. Italy): the Romanengo anticline. Tectonics 33(10):2059-2076. https://doi.org/10.1002/2013TC003422

Brilha J (2016) Inventory and quantitative assessment of geosites and geodiversity sites: a review. Geoheritage 8(2):119-134

Capeder G 1898 Osservazioni geologiche e petrografiche sull'anfiteatro morenico di Rivoli. Tipo-Litografia Toffaloni, Torino, Italy, pp. 15.

Casati E, Olivieri M, Previtali F (1987) Caratteristiche paleopedologiche dei suoli del Pianalto di Romanengo (Cr). Il Fragipan e La Petroplintite Pianura 1:7-42

Cayla N (2014) An overview of new technologies applied to the management of geoheritage. Geoheritage 6(2):91-102. https://doi. org/10.1007/s12371-014-0113-0

Coratza P, Hobléa F 2018 The specificities of geomorphological heritage. In: Brilha J, Reynard E (eds), Geoheritage, pp. 87-106.

Costantini EA, L'Abate G (2009) The soil cultural heritage of Italy: geodatabase, maps, and pedodiversity evaluation. Quaternary Int 209(1-2):142-153. https://doi.org/10.1016/j.quaint.2009.02.028
Cremaschi M (1974) Manufatti del Paleolitico medio - inferiore, provenienti da Monte Netto di Brescia e loro rapporti con i depositi quaternari del Colle. Natura Bresciana 11:41-57

Cremaschi M 1987 Paleosols and vetusols in the Central Po Plain (Northern Italy). Studi e Ricerche sul Territorio: 28, Unicopli Ed, Milano, Italy, $306 \mathrm{pp}$.

Cremaschi M 1990 The loess in northern and central Italy: a loess basin between the Alps and the Mediterranean Sea. C.N.R., Centro di Studio per la Stratigrafia e Petrografia delle Alpi Centrale, Milano, Italy, pp. 187.

Cremaschi M 2004 Late Pleistocene loess. In: Antonioli F, Vai G.B. (eds) Litho-palaeoenvironmental maps of Italy during the last two climatic extremes. Climex Maps Italy, Museo Geologico Giovanni Cappellini, Bologna, Italy, 34-37.

Cremaschi M, Papani G (1975) Contributo preliminare alla neotettonica del margine padano dell'Appennino: le forme terrazzate comprese tra Cavriago e Quattro Castella (RE). Acta Naturalia 11:335-371

Cremaschi M, Christopher C. 1984 Palaeolithic settlement and environment in the middle Pleistocene of Northern Italy: the Ghiardo site. In: The Environment, The Third Conference of Italian Archaeology, vol. I.B.A.R., London, 87-104.

Cremaschi M, Ferraro F 2007 The upper Pleistocene in the Paglicci Cave (Gargano, southern Italy): loess and tephra in the anthropogenic sequence. Atti della Società Toscana di Scienze Naturali - Memorie Serie A: 153-163.

Cremaschi M, Nicosia C (2012) Sub-boreal aggradation along the Apennine margin of the central Po Plain: geomorphological and geoarchaeological aspects. Geomorphologie 2:155-174

Cremaschi M, Trombino L, Zerboni A (2018) Palaeosoils and relict soils, a systematic review. In: Stoops G, Marcelino V, Mees F (eds) Interpretation of micromorphological features of soils and regoliths -, Revised. Elsevier, Amsterdam, pp 863-894

Cremaschi M, Zerboni A, Nicosia C, Negrino F, Rodnight H, Spötl C (2015) Age, soil-forming processes, and archaeology of the loess deposits at the Apennine margin of the Po plain (northern Italy): new insights from the Ghiardo area. Quat Int 376:173-188. https://doi.org/10.1016/j.quaint.2014.07.044

Cremaschi M, Negrino F, Magnani P, Zerboni A, Nicosia C, Rodnight H, Spötl 2016 Il sito Paleolitico di Ghiardo Cave: industrie, cronologia, ambiente. Atti della XLV Riunione Scientifica IIPP 'Preistoria e Protostoria dell'Emilia-Romagna', Studi di preistoria e Protostoria 3, Preistoria e Protostoria dell'Emilia Romagna: $49-58$.

Crouvi O, Amit R, Enzel Y, Gillespie AR (2010) Active sand seas and the formation of desert loess. Quateranry Sci Rev 29:2087-2098. https://doi.org/10.1016/j.quascirev.2010.04.026

De Lima FF, Brilha JB, Salamuni E (2010) Inventorying geological heritage in large territories: a methodological proposal applied to Brazil. Geoheritage 2(3-4):91-99. https://doi.org/10.1007/ s12371-010-0014-9

Delpiano D, Peresani M, Bertola S, Cremaschi M, Zerboni A (2019) Lashed by the wind. Short-term middle Palaeolithic occupations within the loess-palaeosoil sequence at Monte Netto (Northern Italy). Quaternary Int 502:137-147. https://doi.org/10.1016/j. quaint.2019.01.026

Desio A (1965) I rilievi isolati della pianura lombarda ed i movimenti tettonici del Quaternario. Rend Ist Lomb Sci Lett 99(4):881-894

Dingwall P, Weighell T, Badman, T (2005) Geological world heritage: A global framework. Global Theme Study of World Heritage Natural Sites: Protected Area Programme, Switzerland

Dong HM, Song YG, Chen T, Zhao JB, Yu LP (2014) Geoconservation and geotourism in Luochuan Loess National Geopark, China. Quat Int 334-335:40-51. https://doi.org/10.1016/j.quaint.2013. 1010.1023 
Ferrari G, Magaldi D (1976) Il problema del Loess. Studio interdisciplinare del rilievo di Trino Vercellese. Gruppo Di Studio Del Quaternario Padano: Quaderno 3:34-39

Ferraro F (2009) Age, sedimentation, and soil formation in the Val Sorda loess sequence, Northern Italy. Quaternary Int 204:54-64. https://doi.org/10.1016/j.quaint.2008.12.002

Ferraro F 2002 I riempimenti sedimentari delle cavità carsiche e dei ripari sottoroccia come memoria storica delle variazioni climatiche e palaeoambientali del tardo Pleistocene. Unpublished PhD thesis, Università degli Studi di Milano.

Ferraro F, Terhorst B, Ottner F, Cremaschi M (2004) Val Sorda: an upper Pleistocene loesse-palaeosol sequence in northeastern Italy. Rev Mex Cienc Geol 24:30-47

Fitzsimmons KE, Doboş A, Probst M, Iovita R (2020) Thinking outside the box at open-air archeological contexts: examples from loess landscapes in southeast Romania. Front Earth Sci 8:422. https:// doi.org/10.3389/feart.2020.561207

Forno MG (1979) Il loess della collina di Torino: revisione della sua distribuzione e della sua interpretazione genetica e cronologica. Geogr Fis Din Quat 2:105-124

Forno MG (1990) Aeolian and reworked loess in the Turin Hills (northwestern Italy). Quaternary Int 5:81-87. https://doi.org/10.1016/ 1040-6182(90)90027-2

Franzoni E, Graziani G, Sassoni E (2015) TEOS-based treatments for stone consolidation: acceleration of hydrolysis-condensation reactions by poulticing. J Sol-Gel Sci Techn 74(2):398-405. https://doi.org/10.1007/s10971-014-3610-3

Frigerio C, Bonadeo L, Zerboni A, Livio F, Ferrario MF, Fioraso G, Irace A, Brunamonte F, Michetti AM (2017) First evidence for Late Pleistocene to Holocene earthquake surface faulting in the Eastern Monferrato Arc (Northern Italy): geology, pedostratigraphy and structural study of the Pecetto di Valenza site. Quaternary Int 451:143-164. https://doi.org/10.1016/j.quaint.2016. 12.022

García-Ortiz E, Fernández-Martínez F-G, E, (2014) Concepts and terminology for the risk of degradation of geological heritage sites: fragility and natural vulnerability, a case study. Proc Geologist Assoc 125(4):463-479

Gianotti F, Forno MG, Ivy-Ochs S, Monegato G, Pini R, Ravazzi C (2015) Stratigraphy of the Ivrea morainic amphitheater (NW Italy): an updated synthesis. AQM - Alpine and Mediterranean Quaternary 28:29-58

Grandgirard V (1999) L'évaluation Des Géotopes Geologia Insubrica 4:59-66

Guillien Y (1962) Grave, Greze, Gress. Bulletin De L'association Des Geographes Français 303-304:79-81

Guo ZT, Ruddiman WF, Hao QZ, Wu HB, Qiao YS, Zhu RX, Peng SZ, Wei JJ, Yuan BY, Liu TS (2002) Onset of Asian desertification by $22 \mathrm{Myr}$ ago inferred from loess deposits in China. Nature 416:159-163. https://doi.org/10.1038/416159a

Haase D, Fink J, Haase G, Ruske R, Pecsi M, Richter H, Alterman M, Jager KH (2007) Loess in Europeits spatial distribution based on a European loess map, scale 1-2 500 000. Quaternary Sci Rev 26:1301-1312. https://doi.org/10.1016/j.quascirev.2007.02.003

Heller F, Evans ME (1995) Loess magnetism. Rev Geophys 33:211-240

Heller F, Liu TS (1982) Magnetostratigraphical dating of loess deposits in China. Nature 300:431-433

Hirniak JN, Smith EI, Johnsen R, Ren M, Hodgkins J, Orr C, Negrino F, Riel-Salvatore J, Fitch S, Miller CE, Zerboni A, Mariani GS, Harris JA, Gravel-Miguel C, Strait D, Peresani M, Benazzi S, Marean CW (2020) Discovery of cryptotephra at Middle-Upper Paleolithic sites Arma Veirana and Riparo Bombrini, Italy: a new link for broader geographic correlations. J Quaternary Sci 35:199-212. https://doi.org/10.1002/jqs.3158
Jovanović M, Zvizdić O 2009 Geoheritage of the loess sites in Vojvodina. Society of the young researchers Branislav Bukurov (in Serbian).

Krajcarz MT, Cyrek K, Krajcarz M, Sudoł M, Szymanek M, Tomek T, Madeyska T (2016) Loess in a cave: lithostratigraphic and correlative value of loess and loess-like layers in caves from the Kraków-Częstochowa Upland (Poland). Quater Int 399:13-30

Kröhling DM (1999) Sedimentological maps of the typical loessic units in North Pampa, Argentina. Quaternary Int 62:49-55

Kubalikova L, Kirchner K, Kuda F, Machar I (2019) The role of anthropogenic landforms in sustainable landscape management. Sustainability 11(16):4331. https://doi.org/10.3390/su11164331

Kukla GJ (1977) Pleistocene land-sea correlations. Earth-Sci Rev 13:307-374

Laville H, Rigaud JP, Sackett J (1980) Rock shelters of the Perigord: geological stratigraphy and archaeological succession. Academic Press

Lehmkuhl F, Nett JJ, Pötter S, Schulte P, Sprafke T, Jary Z, Antoine P, Wacha L, Wolf D, Zerboni A, Hošek J, Marković SB, Obreht I, Sümegi P, Vere D, Boemke ZC, Schaubert BV, Viehweger J, Hambach U (2021) Loess landscapes of Europe - mapping, geomorphology and zonal differentiation. Earth-Sci Rev 215:103496. https://doi.org/10.1016/j.earscirev.2020.103496

Lenzi F, Nenzioni G 1996 Lettere di pietra e I depositi pleistocenici: sedimenti, industrie e faune del margine appenninico bolognese. Editrice Compositori, Bologna, Italy, pp. 867.

Lercari N, Onsurez L, Schultz J 2013 Multimodal reconstruction of landscape in serious games for heritage: an insight on the creation of fort ross virtual warehouse serious game. In: Kremers H (ed) Digital Cultural Heritage: 2, 231-238. https://doi.org/ 10.1109/DigitalHeritage.2013.6744759

Li Y, Shi W, Aydin A, Beroya-Eitner MA, Gao G (2020) Loess genesis and worldwide distribution. Earth-Sci Rev 201:102947. https://doi.org/10.1016/j.earscirev.2019.102947

Lindner H, Lehmkuhl F, Zeeden C (2017) Spatial loess distribution in the eastern Carpathian Basin: a novel approach based on geoscientific maps and data. J Maps 13:173-181. https://doi. org/10.1080/17445647.2017.1279083

Livio F, Berlusconi A, Michetti AM, Sileo G, Zerboni A, Trombino L, Cremaschi M, Mueller K, Vittori E, Carcano C, Rogledi S (2009) Active fault-related folding in the epicentral area of the December 25, 1222 (Io = IX MCS) Brescia earthquake (Northern Italy): seismotectonic implications. Tectonophysics 476:320-335

Livio F, Berlusconi A, Zerboni A, Trombino L, Sileo G, Michetti AM, Rodnight H, Spötl C (2014) Progressive offset and surface deformation along a seismogenic blind thrust in the Po Plain foredeep (Southern Alps, Northern Italy). J Geo-Phys Res Solid Earth 119:7701-7721. https://doi.org/10.1016/j.tecto.2009.03.019

Livio F, Ferrario F, Frigerio C, Zerboni A, Michetti AM (2020) Variable fault tip propagation rates affected by near-surface lithology and implications for fault displacement hazard assessment. J Stru Geol 130:103914. https://doi.org/10.1016/j.jsg.2019.103914

Lucchesi, S, Gianotti, F, Giardino M 2015 The morainic amphitheater environment: a geosite to rediscover the geological and cultural heritage in the examples of the Ivrea and Rivoli-Avigliana morainic amphitheatres (NW Italy). In Engineering Geology for Society and Territory, 8, 245-248. Springer Ed., Cham. https:// doi.org/10.1007/978-3-319-09408-3_41

Lukić T, Marković SB, Stevens T, Vasiljević DA, Machalett B, Milojković N, Basarin B, Obreht I (2009) The loess cave near the village of Surduk-an unusual pseudokarst landform in the loess of Vojvodina, Serbia. Acta Carstologica 38:227-235. https://doi. org/10.3986/ac.v38i2-3.124

Mancini F (1960) Osservazione sui loess e sui palaeosuoli dell'Anfiteatro orientale del Garda e di quello di Rivoli Veronese. Atti Della Società Italiana Scienze Naturali 99:221-250 
Marković SB, Kostić NS, Oches EA (2004) Paleosols in the Ruma loess section (Vojvodina, Serbia). Rev Mex Cienc Geol 21(1):79-87

Marković SB, Hambach U, Stevens T, Kukla GJ, Heller F, William D, McCoy WD, Oches EA, Buggle B, Zöller L (2011) The last million years recorded at the Stari Slankamen loess-palaeosol sequence: revised chronostratigraphy and long-term environmental trends. Quaternary Sci Rev 30(9-10):1142-1154. https://doi. org/10.1016/j.quascirev.2011.02.004

Marković SB, Stevens T, Kukla GJ, Hambach U, Fitzsimmons KE, Gibbard P, Buggle B, Zech M, Guo Z, Hao Q, Wu H, O'Hara Dhand K, Smalley IJ, Újvari G, Sümegi P, Timar-Gabor A, Veres D, Sirocko F, Vasiljević DA, Jary Z, Svensson A, Jović V, Lehmkuhl F, Kovacs J, Svircev Z (2015) Danube loess stratigraphy towards a pan-European loess stratigraphic model. Earth Sci Rev 148:228-258. https://doi.org/10.1016/j.earscirev.2015.06.005

Martínez-Graña AM, Goy JL, Cimarra CA (2013) A virtual tour of geological heritage: valourising geodiversity using Google Earth and QR code. Comput Geosci 61:83-93. https://doi.org/ 10.1016/j.cageo.2013.07.020

Michetti AM, Bonadeo L, Brunamonte F, Livio F, Fioraso G 2014 Late quaternary evolution and potential for earthquake surface faulting along the Monferrato Arc, N Italy. In: Grutzner C, Choi $\mathrm{JH}$, Edwards P, Kim YS (eds.) Proceeding of the 5th international INQUA Meeting On Paleoseismology, Active Tectonics and Archeoseismology, 39-41.

Mortara M, Catalano CE, Bellotti F, Fiucci G, Houry-Panchetti M, Petridis P (2014) Learning cultural heritage by serious games. J Cult Herit 15(3):318-325. https://doi.org/10.1016/j.culher.2013. 04.004

Muhs DR (2007) Loess deposits, origins and properties. In: Scott AE (ed) Encyclopedia of Quaternary Science. Elsevier, Oxford, pp 1405-1418

Muhs DR, Bettis EA (2003) Quaternary loess-paleosol sequences as examples of climate-driven sedimentary extremes. Geological Society of America Special Paper 370. Boulder. https://doi.org/ 10.1130/0-8137-2370-1.53

Muttoni G, Sirakov N, Guadelli JL, Monesi E, Kent DV, Scardia G, Zerboni A, Ferrara E (2017) An early Brunhes ( $<0.78 \mathrm{Ma})$ age for the lower Paleolithic tool-bearing Kozarnika cave sediments. Bulgaria Quaternary Sci Rev 178:1-13. https://doi.org/10.1016/j. quascirev.2017.10.034

Nicolis E 1899 Triplice estensione glaciale ad Oriente del Lago di Garda. Atti del Regio Istituto Veneto di Scienze, 316-319. Lettere ed Arti: 58-2.

Panizza M (2001) Geomorphosites: concepts, methods and example of geomorphological survey. Chi Sci Bull 46:4-6. https://doi.org/ 10.1007/BF03187227

Panizza M (2009) The geomorphodiversity of the Dolomites (Italy): a key of geoheritage assessment. Geoheritage 1:33-42. https://doi. org/10.1029/2004GL020051

Pecsi M (1990) Loess is not just the accumulation of dust. Quaternary Int 7(8):1-21

Pelfini M, Bollati I (2014) Landforms and geomorphosites ongoing changes: concepts and implications for geoheritage promotion. Quaestiones Geographicae 33(1):131-143. https://doi.org/10. 2478/quageo-2014-0009

Pelfini M, Bollati I, Pellegrini L, Zucali M (2016) Earth Sciences on the field: educational applications for the comprehension of landscape evolution. Rend Online Soc Geol It 40:56-66. https://doi. org/10.3301/ROL.2016.72

Pelfini M, Brandolini F, D’Archi S, Pellegrini L, Bollati I. 2020 Papia civitas gloriosa: urban geomorphology for a thematic itinerary on geocultural heritage in Pavia (Central Po Plain, N Italy). J Maps, 1-9.

Penck A, Brueckner E (1909) Die Alpen im Eiszeitalter. Tauchnitz, Leipzig
Pereira P, Pereira D (2010) Methodological Guidelines for Geomorphosite Assessment. Géomorphologie 16(2):215-222. https://doi. org/10.4000/geomorphologie.7942

Peresani M, Monegato G, Ravazzi C, Bertola S, Margaritora D, Breda M, Fontana A, Fontana F, Jancović I, Karavanic I, Komso D, Mozzi P, Pini R, Furlanetto G, De Amicis MGM, Perhoč Z, Posth C, Ronchi L, Rossato S, Vukosavljević N, Zerboni A (2021) Hunter-gatherers across the great Adriatic-Po region during the last glacial maximum: environmental and cultural dynamics. Quat Int 581-582:128-163. https://doi.org/10.1016/j.quaint. 2020.10.007

Perotti L, Bollati IM, Viani C, Zanoletti E, Caironi V, Pelfini M, Giardino M (2020) Fieldtrips and virtual tours as geotourism resources: examples from the Sesia Val Grande UNESCO Global Geopark (NW Italy). Resources 9(6):63

Pietroni E, Palombini A, Sanna V, Arnoldus-Huyzendveld A 2013 Tiber Valley Virtual Museum: 3D landscape reconstruction in the orientalising period, North of Rome: a methodological approach proposal. In: Kremers H (ed) Digital Cultural Heritage: 2, 223 230. https://doi.org/10.1109/DigitalHeritage.2013.6744758

Pye K (1995) The nature, origin and accumulation of loess. Quaternary Science Reviews, Aeolian Sediments in the Quaternary Record 14:653-667. https://doi.org/10.1016/0277-3791(95)00047-X

Reynard E, Fontana G, Kozlik L, Scapozza C (2007) A method for assessing the scientific and additional values of geomorphosites. Geographica Helvetica 62(3):148-158. https://doi.org/10.5194/ gh-62-148-2007

Reynard E, Perret A, Bussard J, Grangier L, Martin S (2016) Integrated approach for the inventory and management of geomorphological heritage at the regional scale. Geoheritage 8(1):43-60. https:// doi.org/10.1007/s12371-014-0139-3

Romanowska I. 2012 Ex Oriente Lux: a re-evaluation of the lower Palaeolithic of Central and Eastern Europe. In: Ruebens K, Romanowska I, Bynoe R, Ruebens K, Romanowska I, Bynoe R (eds), Unravelling the Palaeolithic. 10 Years of Research at the Centre for the Archaeology of Human Origins. Archaeopress, Oxford, pp. 1-12.

Santos I, Henriques R, Mariano G, Pereira DI (2018) Methodologies to represent and promote the geoheritage using unmanned aerial vehicles, multimedia technologies, and augmented reality. Geoheritage 10(2):143-155. https://doi.org/10.1007/ s12371-015-0164-x

Smalley IJ (1995) Making the material: the formation of silt-sized primary mineral particles for loess deposits. Quaternary Sci Rev 14:7-8. https://doi.org/10.1016/0277-3791(95)00046-1

Smalley IJ, Marković SB, Svircev Z (2011) Loess is almost totally formed by the accumulation of dust. Quaternary Int 240:4-11. https://doi.org/10.1016/j.quaint.2010.07.011

Solarska A, Hose TA, Vasiljević DA, Mroczek P, Jary Z, Marković SB, Widawski K (2013) Geodiversity of the loess regions in Poland: inventory, geoconservation issues, and geotourism potential. Quaternary Int 296:68-81. https://doi.org/10.1080/14724049. 2014.941848

Spinapolice EE, Zerboni A, Meyer MC, Talamo S, Mariani GS, Gliganic LA, Buti L, Fusco M, Maiorano MP, Silvestrini S, Sorrentino R, Vazzana A, Romandini M, Fiorini A, Curci A, Benazzi $\mathrm{S}$, (in press). Back to Uluzzo - archaeological, palaeoenvironmental, and chronological context of the mid-upper Palaeolithic sequence at Uluzzo C Rock Shelter (Apulia, Southern Italy). J Quat Sci. https://doi.org/10.1002/jqs.3349

UNESCO 2010 Guidelines and criteria for national geoparks seeking UNESCO's assistance to join the Global Geoparks Network. http://www.unesco.org/new/fileadmin/MULTIMEDIA/HQ/SC/ pdf/scgeoparcs_2010guidelines.pdf

Vai GB, Cantelli L (2004) Litho-palaeoenvironmental maps of Italy during the last two climatic extremes, map 1 - last glacial 
maximum, map 2 - holocene climatic optimum, 1:1,000,000 scale, 32nd IGC Florence 2004. Museo Geologico Giovanni Cappellini, Bologna

Vasiljević Đ, Marković SB, Hose TA, Basarin B, Lazić L, Stojanović V, Lukic T, Vidìc N, Jovic G, Janicevic SD (2009) The use of webbased dynamic maps in the promotion of the Titel loess plateau Vojvodina, Serbia, a potential geotourism destination. Geograph Pannonica 13(3):78-84. https://doi.org/10.1029/2006GC001565

Vasiljević DA, Marković SB, Hose TA, Smalley I, Basarin B, Lazić L, Jović G (2011a) The Introduction to Geoconservation of loesspalaeosol sequences in the Vojvodina region: Significant geoheritage of Serbia. Quaternary Int 240(1-2):108-116. https://doi. org/10.1016/j.quaint.2010.07.008

Vasiljević DA, Marković SB, Hose TA, Smalley I, O'Hara-Dhand K, Basarin B, Lukìc T, Vujičić MD (2011b) Loess towards (geo) tourism-proposed application on loess in Vojvodina region (north Serbia). Acta Geogr Slov 51(2):391-406. https://doi.org/ 10.3986/AGS51305

Vasiljević DA, Marković SB, Hose TA, Ding Z, Guo Z, Liu X, Smalley I, Lukìc T, Vujičić MD (2014) Loess-palaeosol sequences in China and Europe: common values and geoconservation issues. CATENA 117:108-118. https://doi.org/10.1016/j.catena.2013. 06.005

Venzo S (1957) Rilevamento geologico dell'anfiteatro morenico frontale del Lago di Garda. Parte I: Tratto occidentale GardoneDesenzano. Memorie della Società Italiana Scienze Naturali 2(2):73-140

Venzo S 1961 Rilevamento geologico dell'anfiteatro morenico del Garda. Parte II: Tratto orientale Garda-Adige ed anfiteatro atesino di Rivoli Veronese. Memorie della Società Italiana Scienze Naturali: 13 (1).

Viglino A, Capeder G (1898) Comunicazione preliminare sul loess piemontese. Bolletino Soc Geol Ital 17:81-84

Višnić T, Marković SB, Vasiljević Đ (2013) "Loessland" Project" The development perspectives of the first loess geosite in Serbia Researches Reviews of the Department of Geography. Tour Hotel Manag 42(2013):110-121. https://doi.org/10.3986/AGS51305

Višnić T, Spasojević B, Vujičić M (2016) The potential for geotourism development on the Srem Loess Plateau based on a preliminary Geosite Assessment Model (GAM). Geoheritage 8(2):173-180. https://doi.org/10.1007/s12371-015-0149-9

Vujičić MD, Vasiljević AD, Marković SB, Hose T, Lukić T, Hadzić O, Janićević $S$ (2011) Preliminary geosite assessment model (gam) and its application on Fruška gora mountain, potential geotourism destination of Serbia. Acta Geogr Slov 51-3:361-376. https://doi.org/10.3986/AGS51303

Vujičić MD, Vasiljević AD, Hose T, Tasić N, Morar C, Durić A, Marković SB (2018) A multi-criteria decision analysis with special reference to loess and archaeological sites in Serbia (could geosciences and archaeology cohabitate?). Open Geosciences 10(1):333-343. https://doi.org/10.1515/geo-2018-0026

Wang G, Ye W, Lv Y 2019. Loess geoheritage and geohazard protective measures at Luochuan Loess National Geopark in NW China. Geoheritage: 1-12. https://doi.org/10.1007/s12371-012-0058-0

Warowna J, Zgłobicki W, Kołodyńska-Gawrysiak R, Gajek G, Gawrysiak L, Telecka M (2016) Geotourist values of loess geoheritage within the planned Geopark Małopolska Vistula River Gap, E Poland. Quaternary Int 399:46-57. https://doi.org/10.1016/j. quaint.2015.06.064

Zárate MA (2003) Loess of southern South America. Quaternary Sci Rev 22(18-19):1987-2006. https://doi.org/10.1016/S02773791(03)00165-3

Zerboni A, Trombino L, Frigerio C, Livio F, Berlusconi A, Michetti AM, Rodnight H, Spötl C (2015) The loess-paleosol sequence at Monte Netto: a record of climate change in the Upper Pleistocene of the central Po Plain, northern Italy. J Soil Sedimen 15:1329-1350. https://doi.org/10.1007/s11368-014-0932-2

Zerboni A, Amit R, Baroni C, Coltorti M, Ferrario MF, Fioraso G, Forno MG, Frigerio C, Gianotti F, Irace A, Livio F, Mariani GS, Michetti AM, Monegato G, Mozzi P, Orombelli G, Perego A, Porat N, Rellini I, Trombino L, Cremaschi M 2018 Towards a map of the Upper Pleistocene loess in the Po Plain Loess Basin. Alp Mediterr Quat 31 253-256 https://doi.org/10.26382/AIQUA. 2018

Zhao ZZ, Zhao X, Long CX, Yuan XH, Chen XN 2015 Geoparks in China. In: Errami E, Brocx M, Semeniuk V (eds) From geoheritage to geoparks: case studies from Africa and beyond. Springer International, Cham, pp. 215-232

Zgłobicki W, Baran-Zgłobicka B (2012) Impact of loess relief on land use mosaic in SE Poland. CATENA 96:76-82. https://doi.org/10. 1016/j.catena.2012.04.014

Zgłobicki W, Kołodyńska-Gawrysiak R, Gawrysiak L (2015) Gully erosion as a natural hazard: the educational role of geotourism. Nat Haz 79(1):159-181. https://doi.org/10.1007/s11069-014-1505-9

Zuffetti C, Bersezio R, Contini D, Petrizzo MR (2018) Geology of the San Colombano hill, a Quaternary isolated tectonic relief in the Po Plain of Lombardy (Northern Italy). J Maps 14:199-211. https://doi.org/10.1080/17445647.2018.1443166

Publisher's Note Springer Nature remains neutral with regard to jurisdictional claims in published maps and institutional affiliations. 